\title{
Cyclicality of Credit Supply: Firm Level Evidence
}

\section{Citation}

Becker, Bo, and Victoria Ivashina. "Cyclicality of Credit Supply: Firm Level Evidence." Journal of Monetary Economics (forthcoming).

\section{Permanent link}

http://nrs.harvard.edu/urn-3:HUL.InstRepos:11337408

\section{Terms of Use}

This article was downloaded from Harvard University's DASH repository, and is made available under the terms and conditions applicable to Open Access Policy Articles, as set forth at http:// nrs.harvard.edu/urn-3:HUL.InstRepos:dash.current.terms-of-use\#OAP

\section{Share Your Story}

The Harvard community has made this article openly available.

Please share how this access benefits you. Submit a story.

Accessibility 

H A R V A R D
B U S I N E S S
S C H O O L

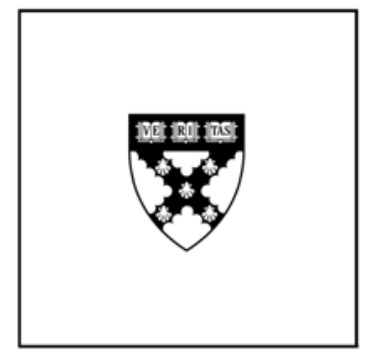

\section{Cyclicality of Credit Supply: Firm Level Evidence}

Bo Becker

Victoria Ivashina

\section{Working Paper}

10-107

August 23, 2011

Copyright (C) 2010, 2011 by Bo Becker and Victoria Ivashina

Working papers are in draft form. This working paper is distributed for purposes of comment and discussion only. It may not be reproduced without permission of the copyright holder. Copies of working papers are available from the author. 


\title{
CYCLICALITY OF CREDIT SUPPLY: FIRM LEVEL EVIDENCE
}

\author{
Bo Becker \\ Harvard University and NBER \\ Victoria Ivashina \\ Harvard University and NBER
}

First draft: May 19, 2010

This draft: August 23, 2011

Theory predicts that there is a close link between bank credit supply and the evolution of the business cycle. Yet fluctuations in bank-loan supply have been hard to quantify in the timeseries. While loan issuance falls in recessions, it is not clear if this is due to demand or supply. We address this question by studying firms' substitution between bank debt and non-bank debt (public bonds) using firm-level data. Any firm that raises new debt must have a positive demand for external funds. Conditional on issuance of new debt, we interpret firm's switching from loans to bonds as a contraction in bank credit supply. We find strong evidence of substitution from loans to bonds at times characterized by tight lending standards, high levels of non-performing loans and loan allowances, low bank share prices and tight monetary policy. The bank-to-bond substitution can only be measured for firms with access to bond markets. However, we show that this substitution behavior has strong predictive power for bank borrowing and investments by small, out-of-sample firms. We consider and reject several alternative explanations of our findings.

Key words: Banks; Financial Markets and the Macroeconomy; Business Cycles; Credit Cycles JEL Codes: E32; E44; G21

We are grateful to Murillo Campello, Erik Hurst, Atif Mian, Joe Peek, Mitchell Petersen, Amiyatosh Purnanandam, Christina Romer, David Romer, Erik Stafford, Jeremy Stein, René Stulz, Luis Viceira, James Vickrey, Vikrant Vig, and seminar participants at the AFA 2011 meeting, the EFA 2011 meeting, Bank of Canada, Bank of Spain, Boston University Boston University Conference on Credit Markets, DePaul, City University of Hong Kong, Harvard Business School, Federal Reserve Bank of St. Louis, European Central Bank, Federal Reserve Board, the London School of Economics, the $3^{\text {rd }}$ Paris Spring Corporate Finance Conference and NBER Monetary Economics workshop for helpful comments. We thank Chris Allen and Baker Library Research Services for assistance with data collection. 


\section{CYCLICALITY OF CREDIT SUPPLY: FIRM LEVEL EVIDENCE}

Theory predicts that there is a close link between bank credit supply and the evolution of the business cycle. Yet fluctuations in bank-loan supply have been hard to quantify in the timeseries. While loan issuance falls in recessions, it is not clear if this is due to demand or supply. We address this question by studying firms' substitution between bank debt and non-bank debt (public bonds) using firm-level data. Any firm that raises new debt must have a positive demand for external funds. Conditional on issuance of new debt, we interpret firm's switching from loans to bonds as a contraction in bank credit supply. We find strong evidence of substitution from loans to bonds at times characterized by tight lending standards, high levels of non-performing loans and loan allowances, low bank share prices and tight monetary policy. The bank-to-bond substitution can only be measured for firms with access to bond markets. However, we show that this substitution behavior has strong predictive power for bank borrowing and investments by small, out-of-sample firms. We consider and reject several alternative explanations of our findings.

Key words: Banks; Financial Markets and the Macroeconomy; Business Cycles; Credit Cycles JEL Codes: E32; E44; G21 
This paper proposes a measure that improves identification of shifts in bank-loan supply. Credit is highly pro-cyclical: not much new credit is issued in recessions. A large theoretical literature suggests that credit supply is important in explaining the evolution of the business cycle. ${ }^{1}$ However, credit could be pro-cyclical because banks are not willing to lend (a supply shift), because firms do not desire to borrow (a demand shift), or both. The central challenge that this paper takes on is to isolate movements in loan supply in a time-series context. Shifts in credit supply and demand differ in terms of welfare costs of financial frictions and the channel through which monetary policy operates. Also, policies that aim to stimulate lending by directly providing financial support to the banks (e.g., the Troubled Asset Relief Program implemented in 2008) are grounded in the idea that bank-loan supply is low in bad times. For all these reasons, it is crucial to tell the supply of loans apart from other cyclical frictions.

To isolate movement in loan-supply, we examine substitution between bank credit and public debt at the firm level, conditional on firms' raising new debt financing. By revealed preferences, if a firm gets debt financing, then the firm must have a positive demand for debt. Thus, by conditioning on new debt issuance, we are able to rule out the demand explanation. (In contrast, if we studied a firm that did not receive new financing, we could not be sure if this was because the firm did not need new financing or because it was not able to raise new financing.) We interpret the substitution from bank debt to public debt as evidence of a shift in bank credit supply. Put differently, if there is a contraction in bank credit supply, ceteris paribus, some firms who would otherwise receive a loan instead have to issue bonds. ${ }^{2}$ (We must rule out some alternative explanations, in particular those related to the relative demand for bonds and loans, and we do so below.)

The idea of using changes in the composition of external finance over the business cycle to identify shifts in bank-loan supply is also central to Kashyap, Stein and Wilcox (1993). They interpret a rise in aggregate commercial paper issuance relative to bank loans as evidence of a contraction in bank-loan supply. The advantage of examining substitution between bank credit

\footnotetext{
${ }^{1}$ E.g., Holmström and Tirole (1997), Bernanke and Gertler (1989), Kiyotaki and Moore (1997), Diamond and Rajan (2005).

${ }^{2}$ In the appendix, we provide a stylized model of bank loan-bond substitution, which provides the key predictions we test. However, these predictions are consistent with much if the theoretical literature and the model serves mainly expositional purposes.
} 
and public debt at the firm level is that it addresses the concern about compositional changes in the set of firms raising debt. ${ }^{3}$

Our firm-level data includes U.S. firms raising new debt financing between 1990 and 2010. Bond issuance data is from Thomson One Banker and loan issuance data is from DealScan which primarily covers large, syndicated loans. ${ }^{4}$ To assure that firms in our sample have access to the bond market, we condition on firms having issued bonds in the last five years. ${ }^{5}$ The intuition of our empirical design can be seen from the following examples: of firms receiving a bank loan but not issuing a bond in 1993, in 1994, 16\% received a loan but did not issue bonds, $3 \%$ issued bonds but did not get a loan, and 4\% did both (77\% did neither). This pattern is similar in most years of the study. Of firms receiving a loan but not issuing a bond in 2003, in 2004, 27\% only received a loan, 6\% only issued bonds, and 5\% did both (52\% did neither). This reveals that firms getting a bank loan are likely to stay with that form of debt in the near future. However, when banks are in distress, this pattern changes. Of firms receiving a bank loan in 2007, in 2008, only 6\% received a loan but did not issue bonds, whereas $17 \%$ issued bonds but did not get a loan, and $2 \%$ did both (75\% did neither). This illustrates that the incidence of bank loans, as compared to bonds, is very cyclical, and that this holds for individual firms (i.e., it does not reflect compositional shifts in who is raising new debt.)

Our first set of results models a firm's choice between bank and public debt as a function of availability of bank credit. (We purposefully focus on the choice of debt (dummy) as opposed to debt amount, because even conditional on positive debt issuance, the amount of debt is likely to be influenced by changes in firm’s investment opportunities.) Given that any single measure of availability of bank credit is imperfect, we use five different variables to proxy for it: (i) tightening in lending standards based on the Federal Reserve Senior Loan Officer Opinion

\footnotetext{
${ }^{3}$ Kashyap and Stein (2000) point out that "perhaps in recessions there is a compositional shift, with large firms faring better than small ones, and actually demanding more credit. Since most commercial paper is issued by large firms, this could explain Kashyap et al. (1993) results.”

${ }^{4}$ For benchmark results, we constrain the sample of term loans (i.e., installment loans) and bonds; however, we later on relax this constrain and find similar result for short-term debt (revolving credit lines and commercial paper), and for a sample including both types of debt.

${ }^{5}$ The idea is that some firms who issued a bond several years ago might have lost their access to the bond market. It is more likely to be the case in bad times and therefore it goes against our findings since we report an increase in relative bond issuance in bad times. In other words, the conditioning can be imperfect without introducing a bias. Nevertheless, in robustness tests we show results for different conditioning horizon with no impact on the overall conclusions.
} 
Survey, (ii) weighted average of banks' non-performing loans as a fraction of total loans, (iii) weighted average of banks' loan allowances as a fraction of total loans, (iv) a market-adjusted stock price index for banks, and (v) a measure of monetary policy shocks based on the federal funds rate deviation from the Taylor-rule. These variables are correlated with aggregate lending volumes, but this may reflect time series variation in either demand or supply for bank credit. By only including firms either issuing bonds or receiving a bank loan in our sample, we isolate the effect of bank credit supply.

All five time-series variables indicate a strong pro-cyclical pattern in the debt financing mix for the firms in our sample. A one standard deviation increase in the net fraction of loan officers reporting tightening in lending standards (24.4 percentage points) implies a 1.4\% decrease in probability of debt financing being a loan. For the other time-series variables, one standard deviation change in the direction of loan supply tightening (higher non-performing loans, higher loan allowances, lower bank stock prices, or tighter monetary policy) predicts a decrease in probability of external credit being a bank loan by $2.7 \%$ to $3.6 \%$. This is large compared to the unconditional average probability of external debt being a loan (13.5\% for the full sample). The results are robust to a battery of controls, to exclusion of the 2007-2009 financial crisis, to sub-periods fixed effects, and several other restrictions.

Our second set of results concerns implementation of the loan-to-bond substitution measure. The substitution between bank loans and public bonds can only be measured for firms with access to both markets. By design, our analysis relies on the least financially constrained firms, whose investment may be the least sensitive to the supply of bank credit. But it is the firms that cannot substitute that are most likely to be affected by a contraction in bank credit. We argue that because substitution between loans and bonds is affected by variation in the loan supply, changes in debt-issuance behavior of substituting firms inform us about conditions of aggregate bank-credit supply. It is a direct prediction, therefore, that our measure has forecasting power for the behavior of firms that are not in our sample. Indeed, we show that the fraction of rated firms receiving a loan (as opposed to issuing a bond) in a given quarter is a strong predictor of a likelihood of raising bank debt for firms which have never issued a bond-i.e., firms that are outof-sample. It also predicts investments for the set of unrated firms that are most dependent on bank lending (firms with high leverage and low market valuation). 
Note that credit to firms without access to the bond market might differ from the types of credit that rated firms get; e.g., loans to large firms are likely to be syndicated, whereas loans to small firms are not. However, the necessary condition for the generalization of our measure is that the different types of bank credit are correlated. We elaborate further on the out-of-sample implications of our measure in the final section of the paper.

To interpret an increase in bond issuance relative to bank debt issuance as a contraction in bank credit supply, we need to address two main alternative explanations. First, the observed substitution from loans into bonds could be a result of an expansion in bond supply. To rule out this hypothesis, we look at the relative cost of the two forms of debt financing. Controlling for credit rating, we find that there is no evidence that bonds are cheaper in periods when the substitution from loans to bonds is highest. Furthermore, the fact that the substitution between bond and loans has predictive power for loan issuance and investments out-of-sample (for firms that lack access to the bond market) reinforces the argument that our findings are not driven by shifts in bond supply.

The second concern is that observed substitution from loans into bonds is a result of expansion in demand for bonds during the economic downturns. The theoretical literature predicts just the opposite. For example, in Diamond (1991), Rajan (1992), Chemmanur and Fulghieri (1994), and Bolton and Freixas (2000), the advantage of bank debt is a result of banks' ability to monitor. These theories stipulate that the preference for public debt over bank debt is more likely for projects of a higher quality, with larger collateral and lower uncertainty about cash flows, so we would expect higher demand for bank debt in recession periods. ${ }^{6,7}$ A more contrived alternative is that the nature of investments (at the firm level) changes over time in such a way that bond financing is more attractive in recessions. For example, due to the contraction in demand for durable goods in recession, firms might shift their production toward

\footnotetext{
${ }^{6}$ These theories are consistent with several cross-sectional empirical patterns. Small and unknown firms tend to be bank borrowers, large and well known firms bond issuers (Hale and Santos, 2008). Firms that issue bonds tend to be more profitable and have more collateral available than firms that borrow from banks (Faulkender and Petersen, 2006), and to borrow at lower interest spreads (Hale and Santos, 2009). Thus, in the cross-section of firms, bank loans are associated with characteristics that become more prevalent in recessions: low profits, low value, and high credit spreads.

${ }^{7}$ Although most of the literature argues that the advantage of bank financing should be strongest for small and more opaque firms, Ivashina (2009) finds that information asymmetry about borrower credit quality is priced into the loan spread for the sample of firms analyzed in this paper.
} 
non-durables goods. This would be a valid alternative explanation if production of non-durable goods would be best financed through bonds. However, this is inconsistent with cross-sectional evidence. In addition, we show that our results hold in a sample of single-segment firms. ${ }^{8}$ Similarly, it is unlikely that our results are driven by a shift from long term investments toward more working capital. Investments are countercyclical, so one would need to believe that working capital is best financed using bonds (as opposed to loans), yet a widely acknowledged flexibility of the bank debt over bonds suggests just the opposite.

Notice that similar to Kashyap, Stein and Wilcox (1993), our research design does not require perfect substitutability between public debt and syndicated bank loans. If substitutability is low, our tests will lack power. But there are several reasons to believe that public debt and syndicated bank loans are fairly close substitutes for firms that have access to the bond market. In particular, both bonds and syndicated loans have similar bankruptcy and corporate tax treatment; they share many contractual features including collateralization and covenants protection, and are comparable in range of maturities and repayment characteristics. ${ }^{9}$ Also, Kashyap, Lamont and Stein (1994) compare inventory investment of firms with and without access to public bond market during economic recessions and attribute lower contraction in inventories of firms with access to public bonds to their ability to substitute between bank credit and public debt. Close substitutability of the two forms of debt for firms with credit rating is also consistent with findings by Faulkender and Petersen (2005). Johnson (1997) shows that firms with access to public debt markets often issue bank loans, suggesting that the requisite substitution behavior may be common.

The contribution of our paper is advancing the measurement of bank credit supply in a business-cycle context. However, the role of bank credit supply in the economy is an old and important question and different empirical approaches had been used to tackle it. Several papers

\footnotetext{
${ }^{8}$ Another proposed explanation of bond issuance in recessions involves a shift from working capital (financed with bank loans) to fixed investment (bond financed) in recessions. However, given lower profits (more need for working capital) and low investment in recessions, this explanation seems contrary to standard business cycle facts.

${ }^{9}$ We do not examine substitution to non-debt forms of external finance. There is a large literature addressing differences between debt and equity financing, going back to Jensen and Meckling (1976) and Myers (1977). Firms raise equity much less frequently than debt. For example, Erel, Julio, Kim and Weisbach (2010) report that US nonfinancial firms issued ten times as much in public bonds as in seasoned equity offerings over the 1971-2007 period, and even more in private debt (loans). For this and other reasons, external equity is unlikely to be a close substitute for bank loans. We abstain from analyzing specific reasons why a firm might choose debt over equity financing.
} 
had focused on exogenous shocks to the bank credit supply in order to establish causal connection between availability of bank credit and firms' activity. Notably, Peek and Rosengren (2000) look at the contraction in the U.S. credit supply caused by Japanese banks in the context of the Japanese crisis in the early 1990s. More recently, Leary (2010) examines expansion in bank credit in the first half of 1960s following the introduction of the certificates of deposits and fall in credit during the 1966 Credit Crunch. Chava and Purnanandam (2011) examine the effects of exogenous disruptions in credit supply in the context of the Russian crisis in the fall of 1998. The evidence in these papers is consistent with the importance of bank credit supply on firms' activity. However, these clear but isolated examples of variation in bank credit supply have limited implications about variation in loan supply over the business cycle. ${ }^{10}$

An alternative approach in the existing literature uses cross-bank variation in access to funding to identify the effect of loan supply on lending volume (e.g., Kashyap and Stein, 2000 and Ivashina and Scharfstein, 2010). These studies are not trivial because one must take a stand on what causes cross-sectional variation in loan contraction and such factors are likely to change over time. But they also have a caveat given that key identifying assumption in these studies is that clients' demand for credit is uncorrelated with banks' access to funding. However, unobservable matching between types of firms and banks makes it a potentially strong assumption. Our methodology relies on within-firm variation in debt issuance, so it is less sensitive to this critique.

The rest of the paper is organized in five sections. Section 1 describes the data. Section 2 examines cyclicality of bank and public debt at the aggregate level using nearly sixty years of data. Sections 3 and 4 present out main results. The first set of result is cyclicality of the substitution between bank and bond financing at the firm level. The second set of results examines predictive power of the substitution between loans and bonds for the small firms. Section 5 concludes.

\footnotetext{
${ }^{10}$ Other examples include Ashcraft (2005) who uses the closure of healthy branches of impaired bank holding companies, and Becker (2007) who uses a demographics-based instrument. These studies are cross-sectional in nature.
} 


\section{Data}

Firm-level data on large syndicated loans issuance comes from Reuters’ DealScan database and covers the period between 1990 and 2010. ${ }^{11}$ Because this period contains two recessions, large fluctuations in bank stock prices, significant changes in monetary policy, and the LTCM crisis in the late 1990s, it promises to allow identification of the cyclicality of firm level choices of bank and market debt. The mean size of the loans in our sample is \$356 million; the median is \$100 million, and 95\% are larger than \$4 million. ${ }^{12}$ Bond data comes from Thomson One Banker data base. We include all non-convertible corporate debt, public and private issues into the U.S. market. We only look at the U.S. firms. We exclude the financial sector from the sample (SIC codes 6000 to 6999); this is important because, at least in the last recession, many of the bond issues by financial firms were backed by government guaranties leading to an unusually large bonds volume issue by banks. For example, according to Standard and Poor's, in the first half of 2009, about 30\% of all new bond issues had some sort of guarantee. ${ }^{13}$ The mean size of bonds issued between 1990 and 2010 was \$236 million; the median was $\$ 175$ million, and 95\% were larger than $\$ 10$ million. $^{14}$

For our base-line results, we compare term loans to bonds; that is, we only include loans that have term loan tranches. In robustness tests, we examine short term credit, i.e., revolvers and commercial paper (CP), and all types of debt at once. We infer CP issuance from Standard \& Poor's instrument level rating data. Since CP is not issued without a rating, and ratings are not obtained without some issuance, we infer a CP issue. The timing may not be perfectly accurate in this procedure, and we may assign some issues to the wrong quarter, inducing some noise. The CP data ends in 2009:Q3, a few quarters before the end of our main sample. To avoid including firms without access to the bond market, we start by conditioning the sample to firms that issued bonds in the last five years. However, in the robustness tests we verify that this condition is not driving our results.

\footnotetext{
${ }^{11}$ DealScan coverage goes back to late 1980s; however, the coverage is uneven and primarily concentrated on large LBO deals.

${ }^{12}$ These summary statistics excludes bank loans received in quarters where a firm also issued bonds or received more than one loan. Overall statistics (i.e. including the extra observations) are similar.

13 “Corporate bond issuance sets record,” Wall Street Journal, 24 July 2009.

${ }^{14}$ This data represents statistics for the sample of bonds issued by firms which did not receive a bank loan in the same quarter, and did not issue more than one bond. Overall statistics (i.e. including the extra observations) are similar.
} 
Firm financial data comes from Compustat. The identification will be driven by firms that issue both bank and public debt. Approximately 59\% of the Compustat firms with bond issue data also issue loans as reported in DealScan. (Our loan sample excludes “amend and restate” cases which are not new loan issuances but often are recorded as such by DealScan.) The data used in the analysis is organized as a panel of firm-quarter observations from 1990:Q2 to 2010:Q4. There are 21,053 firm-quarter observations (9.4\% of Compustat firm-quarters) with new debt issuance by the broadest definition (including revolving lines and commercial paper), and 12,227 firm-quarters (5.5\%) by the narrower definition (term loans and bonds only) that we use as baseline. ${ }^{15}$ In a third of all firm-quarters with debt issuance, debt issues are new loans by the narrower definition, and, by the broader definition, in two thirds (the difference is due to the fact that many more firms have credit lines than issue commercial paper). We focus on the 5.3\% of Compustat firm-quarters with one (but not both) kinds of new debt (baseline). ${ }^{16}$

Figure 1 illustrates that in the most recent financial crisis, there was a considerable shift from bank loans to bonds, starting in late 2007. It became particularly pronounced in the fourth quarter of 2008 and continued through the first three quarters of 2009. Between 2009:Q4 and 2010:Q4, despite a modest recovery, firms issuing loans as a fraction of firms issuing debt remained significantly below its historic levels with $14.8 \%$ of public firms issuing bank debt on average (a 62\% drop as compared to 2006). This result suggests that bank credit supply had remained depressed throughout 2010. This conclusion is in sharp contrast to the patterns suggested by the Senior Loan Officer Opinion Survey. That said, we want to highlight a clear negative correlation between the firms issuing loans as a fraction of firms issuing debt and the net percentage of banks tightening credit standard collected as part of the Senior Loan Officer Opinion Survey on Bank Lending Practices in the overall sample (0.37 in Figure 1, Panel A and 0.46 in Panel B). This is remarkable since the construction of the two indicators has little to do with each other.

\footnotetext{
${ }^{15}$ Note that missing observations_-firm quarter in Compustat where no new debt was issued_are excluded by design to rule out lack of demand for credit. In other words, each observation in our sample corresponds to an unambiguous willingness to get debt. Thus, if a firm did not get a loan it cannot be because it did not demand new credit.

${ }^{16}$ We exclude quarters with issuance of both types of debt for methodological reasons. However, simultaneous issuance of both types of debt is typically associated with large corporate transactions such as takeovers and recapitalizations. We are interested in the real economic activity and, in that sense, exclusion of these transaction is consistent with the focus on general purpose corporate financings.
} 
According to the Federal Reserve Board, the information obtained from the survey is one of the key macroeconomic indicators about the credit market conditions, and it is reported regularly to the Board of Governors and to the Federal Open Market Committee as part of the internal briefing materials that are used in formulation of monetary policy. ${ }^{17}$ Although survey information provides valuable insights about credit conditions, as any survey data, it might be a reflection of beliefs as opposed to actions. The interpretation of the survey data becomes particularly sensitive for questions that aim to understand whether the observable credit conditions are driven by supply or demand. ${ }^{18}$ Therefore, the frequency of bank credit in new debt funding of large firms appears to contain valuable information beyond the survey data.

\section{[FIGURE 1]}

Table 1 summarizes the composition of the sample and firm level characteristics. Throughout the analysis, we include firm-fixed effects in addition to other firm-level control variables. In particular, for each firm-quarter, we calculate the log of the previous quarter's assets and the log of the previous quarter's property, plant and equipment. We also compute the return on assets as operating income before depreciation divided by previous quarter's assets and the one year lagged return to the end of the previous quarter (the log of the previous quarter's closing stock price minus the closing stock price five quarters ago). We also include an indicator variable for firms paying a dividend in the current of the analysis.

\section{[TABLE 1]}

We use five time-series variables to track variation in banks' willingness to lend over time (all of the time-series variables are quarterly):

- $\quad$ Tightening in lending standards: The data comes from Federal Reserve Senior Loan Officer Opinion Survey on Bank Lending Practices. The series corresponds to the net percentage of domestic respondents tightening standard for commercial and industrial (C\&I) loans to large and medium-sized firms. ${ }^{19}$ A higher value indicates that more banks

\footnotetext{
${ }^{17}$ For further information see http://www.federalreserve.gov/boarddocs/snloansurvey/about.htm.

18 There are specific questions in the survey asking about "demand" for credit; however, answers given to these questions may not be independent of changes in credit standards (the questions are certainly not phrased that way.) Lenders might observe fewer loan applications as a result of tightening lending standards, thus the causal relation between supply and demand of credit is not clear from the answers to the survey.

${ }^{19}$ The survey separately asks about lending to small firms and lending to large and medium firms, however the correlation between tightening in lending standard for the two groups in our sample is 0.97.
} 
report tighter credit standards (contraction in bank credit). The measure ranges from $-24.1 \%$ in quarter 2005:Q2 to $74.5 \%$ in 2008:Q4. ${ }^{20}$

- Non-performing loans: The ratio of non-performing loans to total loans. The data was compiled from Consolidated Report of Condition and Income (known as Call Reports) and correspond to asset-weighted averages for Bank of America, JPMorgan Chase, Citibank, Wells Fargo, Bank of New York, US Bancorp, Fifth Third Bancorp, Wachovia, Toronto-Dominion Bank, CIT, SunTrust, KeyCorp, Regions Financial, Comerica, PNC and National City Corporation. ${ }^{21}$ A higher value is likely to be associated with a contraction in bank credit supply.

- Loan allowances: The ratio of loan allowances to total loans. Similarly to the nonperforming loans, the data was compiled from Call Reports using the same set of banks listed above. We use asset-weighted averages by quarter to consolidate the data across different banks. Whereas non-performing loans is based on realized losses, loan allowances is a forward looking measure of the bank-portfolio quality. A higher value is likely to be associated with a contraction in bank credit.

- Bank stock-index: The logarithm of the level of the market-adjusted price for banks using industry return data originally introduced by Fama and French (1997) and available from Kenneth French’s on-line data library (industry number 44 in the forty eight industry portfolio, with the name "Banking"). A higher value is likely to be associated with an expansion of bank credit.

\footnotetext{
${ }^{20}$ Although the net percentage of domestic respondents tightening lending standard is a widely used measure it does not reflect the level of tightening in credit. For example, in 2006:Q1 as well as in 2010:Q4 on net 7.1\% of the banks were loosening their lending standards to small firms, however the lending standards at the end of 2010 were still likely to be much tighter than those in early 2006. There is no clear way of addressing this issue using the survey data. So, as a robustness test, we used a time series of average Maximum Debt-to-EBITDA covenant for large corporate loans compiled by S\&P Leveraged Commentary and Data; the data runs 1998:Q4 forward. This is an alternative measure of tightening in lending standards that is comparable across time: In 2006:Q1 average Maximum Debt-to-EBITDA was 4.43 and it was 4.37 in 2010:Q4 (1.1 higher than its lowest level in 2009:Q1). The correlation between the two measures is -0.51 . As with other macro indicators, we find a strong economic and statistical connection between the substitution measure of credit supply conditions proposed in this paper and credit conditions as measured by the Maximum Debt-to-EBITDA covenant.

${ }^{21}$ The list corresponds to the largest U.S. lenders. Although ex-investment banks are important participants in the syndicated loan market (i.e., large and medium corporate lending) they are not part of the sample because they were not required to file Call Reports before the two surviving banks became bank holding companies in September of 2008.
} 
- Tightening monetary policy: A measure of the unexpected tightening in monetary policy constructed as deviation of the federal funds rate from the target level. The target level is computed using Taylor-rule (Taylor, 1993.) ${ }^{22}$ A reduction in the federal fund rate could be a response to a fall in consumers' demand; an expansionary monetary policy would still likely have an effect on credit supply, however the interpretation of the net (observable) effect on credit is less clear. Thus, the idea of using deviation of the federal fund rat is to identify instances when monetary policy is likely to have an exogenous effect on the credit supply. ${ }^{23} \mathrm{~A}$ higher value indicates tighter monetary policy, which is likely to be associated with a contraction in bank credit.

\section{Cyclicality of bank and public debt at the aggregate level (1953-2010)}

Before turning to firm level data, we examine the cyclicality of the aggregate stock of bank credit. This step is important for understanding the potential magnitude of bank debt for macro-economic volatility and business cycles. We construct the time series of aggregate U.S. corporate debt from Flow of Funds data, reported by the Federal Reserve Bank. For bank debt, we combine data on Other Loans and Advances and Bank Loans Not Elsewhere Classified. For public debt, we add up Commercial Paper and Corporate Bonds. Data on economic recessions is from the National Bureau of Economics Research (NBER).

As can be seen from Figure 2, the growth of total credit outstanding for U.S. nonfinancial firms is highly pro-cyclical. Several patterns are striking. Of the two types of credit, bank debt is both more volatile and more cyclical than public debt. Second, bank debt often shrinks rapidly, whereas the outstanding stock of market debt never falls year-to-year. Third,

\footnotetext{
${ }^{22}$ Real Potential Gross Domestic Product is compiled by Congressional Budget Office. Real Gross Domestic Product is compiled by Bureau of Economic Analysis. Consumer Price Index for All Urban Consumers (All Items) is compiled by Bureau of Labor Statistics. Effective Federal Funds Rate is compiled by Board of Governors of the Federal Reserve System. All series can be downloaded from Federal Reserve Bank of St. Louis: http://research.stlouisfed.org/fred2/.

${ }^{23}$ Deviation of the federal rate from the Taylor rule has important limitations when applied to Greenspan era of monetary policy. Several studies had come out with alternative ways of measuring monetary shocks. In unreported results, we use the measure originally proposed by Romer and Romer (2004) and extended by Barakchian and Crowe (2010). (The original Romer and Romer (2004) sample runs through December 1996; updated data can be downloaded from Christopher Crowe IMF web site.) Although economically important, this measure of monetary shocks has a statistically weak correlation with the proposed measure of loan-to-bond substitution with $p$-value of 0.2 for the firm-level results.
} 
several recessions - notably, the three most recent NBER recessions-exhibit rapidly shrinking bank debt at some point during the recession. Public debt is more stable and less affected by recessions. These facts appear consistent with a business cycle role for the supply of bank credit similar to that proposed by Holmström and Tirole (1997).

\section{[FIGURE 2]}

Figure 2 also illustrates that our argument—substitution from (to) bank debt into public debt as a measure of bank-credit supply contraction (expansion) —is consistent with the exogenous shifts in bank credit supply documented in the previous literature. Leary (2010) points out a gradual expansion in bank credit between 1961 and 1966 following the emergence of the market for certificate deposits. Indeed, in the first half of 1960s one can see a rise in relative share of bank debt as the growth rate of bank credit accelerates while the growth of public debt slows down. This is sharply reversed in the 1966 Credit Crunch (Leary, 2010). Similarly, the shift in relative composition of corporate debt is clear following the burst of the Japanese real estate bubble (Peek and Rosengren, 2000) and the 1998 Russian debt crisis followed by the LTCM collapse (Chava and Purnanandam, 2011). These shocks to the supply of bank loans are visible in Figure 2, in that they coincide with or precede changes in the relative growth in corporate debt stocks.

The aggregate statistics for the growth in the total value of bank and public debt outstanding are presented in Table 2, Panel A. The growth of two forms of debt finance for nonfarm, non-financial, corporate business in the U.S. has been remarkably similar for the last sixty years: $6.83 \%$ average real four quarter growth for market debt and 6.17\% for bank debt (the difference is statistically insignificant). The stock outstanding at the end of quarter 2011:Q1 was 1.65 trillion dollars of bank debt and 4.66 trillion dollars of market debt, 11\% and 31\% of GDP, respectively. Bank debt was more important in relative terms in the middle of the sample, and actually exceeded the value of market debt in 1982 and 1983.

[TABLE 2]

While the average growth rates have been very similar, the volatility of bank debt has been much higher than that of market debt. Over 1952:Q4-2011:Q1, the standard deviation of the real quarterly growth in the stock of bank debt is 7.8\%, more than twice as high as the $3.6 \%$ 
standard deviation for market debt. This difference is highly statistically significant. ${ }^{24}$ During the sample period, there have been fifty-one quarters where bank debt was lower in real terms than it had been four quarters earlier, but not a single quarter where the outstanding stock of bond finance was lower than four quarters earlier (Table 2, Panel A also shows various moments of the two distributions of growth rates).

Not only is the stock of bank debt outstanding more volatile than the stock of public debt, it is also much more cyclical. Whereas the real growth in public debt is uncorrelated with GDP growth, the growth in bank debt is significantly positively correlated with the GDP growth. In Panel B of Table 2, the real growth of the debt stock is regressed on growth the preceding quarter, a dummy for whether any month in the quarter was classified as belonging to a recession by NBER and real, four quarter GDP growth. This is done separately for the two kinds of debt. The growth of market debt is highly autocorrelated, with an estimated coefficient of 0.94 on lagged growth. ${ }^{25}$ However, its relation to GDP growth and to the recession indicator is statistically and economically insignificant. Bank debt growth is similarly autocorrelated, but also strongly related to GDP growth (but not the recession indicator). The coefficient on real GDP growth is 1.2, indicating that a 1.2\% drop in growth (corresponding to one standard deviation of the four quarter real GDP growth variable) predicts a $1.4 \%$ drop in the rolling fourquarter real growth rate of bank debt (holding lagged growth fixed). These regressions illustrate how pro-cyclical bank debt is, especially in comparison with market debt. This point is also clear from Figure 2.

The average maturity of bonds exceeds that of loans. Could this mechanically increase the cyclicality of the stock of bank debt (as compared to the stock of bond debt)? The shorter the maturity, the larger the volume due-for-refinancing is. If both loan and bond markets shut down, the total amount of loans outstanding would fall faster, but this is unlikely to be an explanation for our findings. We never see the hypothetical scenario of no bond issuance; as one can see in Figure 2, the growth rate of bonds is always strictly positive. Moreover, in firm level data, we control for the maturity of issued debt as well as firm fixed effects.

\footnotetext{
${ }^{24}$ Even allowing for the overlapping nature, the $p$-value of the difference for the standard deviations is below $0.1 \%$. The difference in means is insignificant ( $t$-stat 0.28 ).

${ }^{25}$ To some extent, this autocorrelation is induced by using overlapping four quarter growth rates as observations, but it is apparent also in non-overlapping data. We make no inferences based on the coefficient on lagged growth.

Rolling four quarter growth rates have the advantage of removing any seasonality from the time series.
} 
The cyclicality of bank debt can reflect cyclical variation in the relative demand for bank debt, shifts in the relative supply of bank debt, or both. If we knew for sure that the demand for intermediated credit rises in bad times, aggregate evidence that the stock is counter-cyclical would be enough to establish that bank supply is highly variable and counter-cyclical. As pointed out above, theories of intermediated debt and market debt suggest that bank debt is more attractive in bad times, because it is more flexible and it brings superior monitoring. These theories support a counter-cyclical relative demand for bank debt. However, market debt tends to be available for larger firms, and large firms may have a pro-cyclical share in aggregate investment. More generally, if the set of firms that tend to issue bonds differ from those that borrow from banks, the cyclicality of these groups of firms might affect the evolution of aggregate debt stock even if supply never moved at all. Aggregated data cannot address whether compositional changes in the type of firms raising debt finance can explain the observed cyclicality. We therefore turn to firm level data.

\section{Results: Cyclicality of bank and public debt at the firm-level}

\section{A. Benchmark results}

In this section, we present results for a firm-quarter panel of new debt financing. We model how aggregate time-series variables that are likely to be related to bank lending supply explain the mix of new debt issuance. We rely on the revealed preference argument that any firm raising outside debt has non-zero demand for credit. This allows us to interpret coefficient estimates on the time-series variables as evidence of how supply varies over time.

Throughout the analysis we use quarterly data because this corresponds to the highest frequency of data available for both accounting data and three of the time-series variables. The sample of firm-quarters excludes any firm-quarter where no debt was raised or where both bonds and bank debt was raised. ${ }^{26}$ Because firms raise new debt financing only occasionally, the panel is unbalanced. For firms appearing more than once in our sample, there are 4 observations on average. We construct a quarterly indicator of the debt choice $\left(D_{i t}\right)$ equal to 1 if a firm receives bank loan and 0 if a firm issues a bond. Our baseline results only considers term loans (no

\footnotetext{
${ }^{26}$ The number of firm-quarters where firms raise both types of debt are rare $(0.2 \%$ of firm-quarters with new debt) and are likely to be associated with large corporate events such as mergers.
} 
revolving credit lines) and bonds (no commercial paper), but we vary these definitions in robustness tests (see Table 8). Multiple loan issues in the same quarter are counted as one, similarly for bond issues. The estimated equation is of the following form:

$$
D_{i t}=\alpha_{i}+\beta b_{t}+\gamma X_{i t}
$$

where $D_{i t}=1$ if the firm $i$ obtained a bank loan in quarter $t$ and $D_{i t}=0$ if the firm obtained a bond; $b_{t}$ is a time-series measure capturing banks' willingness to lend; and $X_{i t}$ is a set of controls, specific to the firm $i$. $X_{i t}$ includes the log of assets (lagged), the log of property, plant and equipment (lagged), the return on assets (operating income before depreciation divided by preceding quarter's assets, lagged), one year lagged return to the end of the previous quarter, leverage (long term debt over assets, lagged), and a dummy indicating whether a firm pays a dividend in the current quarter. The benchmark specification does not include the amounts, maturity, and many other features of the debt. ${ }^{27}$ Overall, we have slightly less than ten thousand observations with data on all controls. Equation (1) is estimated using ordinary least squares (OLS), with errors clustered by quarter since this is the dimension on which the variables of interest vary. ${ }^{28}$

Table 3 presents our first main result. In Table 3 column one, the cyclical variable is the net fraction of loan officers reporting tightening credit standards, predicted to be negatively correlated with banks' willingness to lend. Indeed, the coefficient is negative and significant. The coefficient point estimate, -0.059 , implies that a one standard deviation increase in lending standards is predicted to decrease the probability that a firm gets a loan, conditional receiving debt financing, by $1.4 \%$ (or, equivalently, that the fraction of external debt financings that is made up of bank loans will be lower by 1.4\%). In other words, firms appear to substitute bonds for bank loans at times when lending standards are tight. This is unlikely to reflect a drop in

\footnotetext{
${ }^{27}$ We would like to control for the borrower's desired maturity and amount, but realizations are not good controls. Conditioning on such contract features may bias our results. This can happen if maturity and amount partially reflect supply (i.e. are not completely driven by borrower preferences), in which case realized values of these variables will be correlated with the dependent variable, introducing reverse causality between dependent variable and a control. Therefore, it is not clear if including realized values as controls improves estimates. We include these and other variables as additional controls in robustness tests.

${ }^{28}$ Equation (1) could be estimated with logit or probit, but these require additional assumptions, e.g. about functional forms (which OLS does not require to be unbiased) without offering any obvious compensating advantage in our setting (Angrist and Pischke, 2009).
} 
demand, since all the firms in the sample receive external credit in some form. Therefore, we interpret this as evidence for cyclical lending supply from banks. The firm level control variables show some predictive power, notably leverage (high values of the variable predict loans), and the dividend payer dummy (payers tend to issue bonds). The regression in column one has a fairly high $R$-squared, 39\%, mostly due to the effect of the approximately two thousand firm fixed effects. The $R$-squared could be driven by cross-sectional predictability, but, in fact, the pure time-series $R$-squared of the firm fixed effects is also high ( $34 \%$ for the full sample). ${ }^{29}$ This suggests that compositional effects are indeed important in explain the use of bank vs. bond loans, and validates the use of fixed effect specifications.

[TABLE 3]

We next repeat the regression with our second time-series measure, the ratio of nonperforming loans to total loans for large banks. (The number of observations is smaller for this time series variable, because quarterly information is consistently available from 1993:Q4 onwards.) Because it is based on accounting data, the fraction of non-performing loans is less subjective than the survey based measure. Like lending standards, it is highly correlated with aggregate lending volumes. This variable is likely to drive lending only if bank capital is costly or difficult to raise, so that non-performing loans (which will reduce bank capital) makes lending more difficult. The coefficient estimate in column two is negative and significantly different from zero, implying a 3.4\% increase in the probability of a bank loan for a one standard deviation decrease in non-performing loans.

In column three we use an alternative accounting based-variable, large banks' loanallowances as a fraction of total loans. Non-performing loans is a backward-looking measure, whereas loan allowances reflects expected losses. The effect is negative and significant, implying a 3.6\% drop in the fraction bank loans when bank accounts show large losses.

In column four, we use the bank stock-index. This is a forward-looking measure of banks' performance. The coefficient implies that a one standard deviation increase in the stock

\footnotetext{
${ }^{29}$ By pure time series $R$-squared we refer to the explanatory power of estimates of the bond-bank loan mix using only the firm fixed effects and no other controls, where we treat each quarter as one observation when calculating the $R$-squared.
} 
price of banks relative to the market increases the likelihood that a firm gets a loan (conditional on getting external credit) increased by 3.1\%.

Finally, in column five, we use our measure of unexpected tightening in monetary policy. This traces a parallel with Kashyap, Stein and Wilcox (1993); in their work, periods of tightening monetary policy are used as instances where one should expect a shift in credit supply. Again, the result is highly significant. The implied increase in the fraction of bank loans for a one standard deviation increase in the policy variable is $2.7 \%$.

Using five predictors of bank willingness to lend constructed from different data sources and with different time series properties, we find that the fraction of new credit that is sourced from banks falls rapidly with bank financial health and economic environment. The expected change in the bank fraction of new credit for a change from the $10^{\text {th }}$ to the $90^{\text {th }}$ percentile of the distributions ranges from $4 \%$ (lending standards) to 24\% (monetary policy shocks). Our use of bond credit as the alternative to bank loans has dealt with demand explanation, and firm fixedeffects rules out compositional changes in the population of firms raising credit. In other words, it appears bank-loan supply_as measured by firms' choice of debt-is highly cyclical. Two key caveats that remain are the potential cyclicality of bond supply and the nature of firm investment. We consider these in the next section.

\section{B. Alternative explanations}

By design, our results rule out the demand-driven explanation in the contraction of bank credit. However, we need to address other alternative explanations. In particular, a switch from bank debt to bonds in times of low growth and poor bank health could be caused by countercyclical bond supply (instead of cyclical loan supply). As we will show later, the fact that the substitution between bond and loans has predictive power for loan issuance and investments outof-sample (for firms that lack access to the bond market) makes it unlikely that our results are driven by shifts in bond supply. However, we can also assess this by examining the relative cost

of bonds and loans. If shift in bond supply could explain our findings, we should observe a negative correlation (bonds to become cheaper as compared to bank loans) between the relative cost of loans and the share of firms issuing loans among the firms issuing debt.

To compute the relative cost of the two forms of debt we do not rely on the secondary market prices, but instead use information at issuance. Bonds typically pay a fixed coupon rate. Loans, on the other hand, include some fees (e.g., an annual fee) and a fixed spread paid over 
(London Interbank Offered Rate) LIBOR. Therefore, to compare bond yield to maturity at issuance to loans all-fees-in spread, for each bond we subtract LIBOR swap rate of the same maturity from the yield-to-maturity. ${ }^{30}$ We use daily data for swap rates and match bond issuance date to the date of the LIBOR swap. Bonds and loans are then grouped by maturity and credit rating. We take an average of all-fees-in spread and yield-to-maturity net of LIBOR swap rate by maturity and credit rating. We do it first for each month and then across months for each quarter. Yield to maturity on bond issues is from Thomson One Banker. For loans, the data is from DealScan. ${ }^{31}$

In Table 4 we report correlations between the relative cost of loans (as compared to bonds), the measure of conditions in bank-credit supply that we propose and the five time-series that we use to track variation in banks' willingness to lend over time. We report correlations for an average of the relative costs for bonds and loans with 3- to 10-year maturity. We use the loans and bonds rated $\mathrm{A}, \mathrm{BBB}, \mathrm{BB}$, and $\mathrm{B}$ (the groups for which there is sufficient frequency of issuance for both types of debt over the period of our sample). Most of these correlations are economically small and statistically insignificant. In cases where correlations are statistically different from zero, the sign of the correlations suggest that bank loans are actually cheaper in bad economic times. ${ }^{32}$ Similar results emerge from correlations during NBER recession periods. Thus, the results in Table 4 strongly reject the bond supply explanation of the quantity findings. It appears that firms issue bonds when banks are reluctant to lend, and that they do it despite bonds being marginally more expensive. (In the appendix, we provide intuition for why the relative bond price might rise when banks are substituting from loans to bonds. ${ }^{33}$ )

[TABLE 4]

\footnotetext{
${ }^{30}$ Data on LIBOR swap rates at different maturities is compiled by the Federal Reserve (see http://www.federalreserve.gov/releases/h15/). Historical data was downloaded using DataStream.

${ }^{31}$ We assume that loans are placed at par based on the fact that between 2001 and 2007 average issuance price was 99.8 cents on a dollar, with a standard deviation of 0.6 cents (S\&P Leveraged Commentary and Data).

${ }^{32}$ Santos and Winton (2011) look at the evolution of loan spreads over the business cycle for a cross-section of firms. They conclude that firms with public debt-market access pay lower spreads and, as compared to bankdependent firms, their spreads rise significantly less in recessions. Although our focus is on the relative cost of bonds and loans, these cross-sectional findings are consistent with our results.

${ }^{33}$ Also note that this yield ratio is probably a noisy measure of pricing conditions. Several studies had shown that relevant terms of loans and bonds include the nature and tightness of covenants in addition to other characteristics. Most importantly, this overall pricing measure may not capture the (counter factual) price of the type of credit a firm did not get in a given quarter.
} 
We can also rule out a relative price-based explanation of a cyclical debt mix by directly controlling for the relative cost of loans in our regressions. For each quarter, we use the ratio of loan spreads to bond yields net of LIBOR swap rate to that of bank loans. The ratio is matched to the loan based on credit rating and maturity. The results are reported in Table 5. For brevity, we report only the coefficient on the time series variable and the significance of that coefficient estimate (i.e., each number corresponds to a different regression). The first row of Table 5 reports the benchmark results from Table 3. The key estimates remain largely unaffected by the inclusion of this additional control. This result reiterates our conclusion that the variation in the debt mix that we have documented likely does not reflect firm's attempt to time the yield curve.

Because loans are typically variable rate instruments and bonds are fixed rate instruments, we must consider a possibility of time-varying preferences for fixed vs. variable rates more broadly. In particular, if firms find fixed rates more attractive in recessions, this would mechanically increase bond issuance. But the existing evidence suggests just the opposite. Koijen, Van Hemert and Van Nieuwerburgh (2009) show that when bond risk premium increases even less sophisticated financial agents like household prefer variable rate to fixed rate. ${ }^{34}$ On the other hand, we know that the yield curve is steeper in economic downturns (e.g., Estrella and Hardouvelis, 1991). This implies that in recessions, firms which prefer low current interest payments should prefer to issue debt priced with short rates, which is typically done through loans. Thus, based on the preference for variable rate, the demand for loans should increase in recessions.

The second potential caveat to the credit supply-based interpretation of our benchmark findings is that for a given firm, bond financing becomes more attractive in recessions. I.e., although by construction we know that firms in our sample have non-zero demand for debt, there could be a relative shift in demand for bonds at the firm level. ${ }^{35}$ As discussed in the introduction, many theories predict that in economic downturns, firms are likely to prefer bank debt because of its advantages in monitoring and renegotiation. Yet, there could be other distinctive features of public debt that could make it the preferred choice of financing in recessions, perhaps for a

\footnotetext{
${ }^{34}$ Note that, like corporate loans, variable rate mortgages are often contracted over LIBOR.

${ }^{35}$ Let us reiterate that, because we use firm fixed effects in all regressions, the only investment shifts that might explain our results are those that occur within firm. Thus, we focus only on such explanations. It is very likely that there are compositional shifts in the pool of firms raising debt over the economic cycle, and that is precisely the motivation for using firm-level fixed effect specifications throughout the analysis.
} 
subset of firms. For example, if the choice of bank versus public debt is determined by the tradeoff between liquidation cost in bankruptcy (which is higher for public debt) and the disciplining role of non-renegotiation (which is weak for bank debt), then a firm will switch to bonds if it perceives that the expected cost of liquidation is low (Bolton and Scharfstein, 1996). It is difficult to come up with a realistic explanation for why expected liquidation costs would be procyclical. ${ }^{36}$ Given the absence of models predicting bond-preferences in distressed firms, we conclude that standard theory agrees with assigning the cyclical patterns we observe to the low supply of banks in bad times, in line with Holmström and Tirole (1997).

However, there are other caveats, based on arguments that may not have been as carefully formalized in the literature. It is possible that in bad economic times, firms focus on manufacturing different products. If some types of investments are better financed by bonds, it might lead to a cyclical pattern relative to demand for bank loans. For example, if bond debt is more suitable for financing of non-durable goods, which tend to be less cyclical, a contraction in durable consumption in recessions could be the driver behind substitution from bank loans to bond debt. Sorting firms into durable and non-durable industries using Fama and French (1997) classification, we examine the debt mix of the various groups of firms. In our panel, firms in non-durable industries do not use bond debt more frequently than durable industries (the bank fractions are $13.0 \%$ for non-durable, $14.1 \%$ for durable industries). So, the cross sectional evidence is inconsistent with such prediction.

A more direct way of ruling out changes in the nature of investment as an explanation for our findings is to test our predictions in a sample of single-segment firms. The idea is that the single-segment firms must be less able to switch the nature of investment than multi-segment firms. We use segment data from the Compustat Segment Database and define a firm as multisegment in a year it reports business segments in two distinct Fama-French industries, each with sales and assets above $10 \%$ of firm total. ${ }^{37}$ A firm is classified as single-segment if it does not report such segments. This reduces the sample size by a quarter. The third row in Table 5 reports

\footnotetext{
${ }^{36}$ Notice that, at the firm level, we find an increase in bond issuance. Thus, it cannot be the case that firms are simply giving up projects that are best financed by bank debt and choosing projects that are best financed by bonds. But, even if they did-i.e., if there is projects substitution at the firm level,-it would still imply a contraction in bank credit supply.

${ }^{37}$ For 2009 and 2010, the segment data is incomplete, and we use the 2008:Q4 classification where available. The $10 \%$ cutoff is not important for our conclusions, and we get very similar results with 5\% or $20 \%$.
} 
regressions results for single-segment firms only. Coefficients are very similar in magnitude and significantly different from zero in all cases. These results imply that change in the nature of investments over the business cycle is an unlikely explanation for our findings.

\section{Subsamples based on firm characteristics}

We next consider how the supply response we have identified in the full sample may vary across firms. Several papers have pointed to the likelihood that some firms suffer more than others when bank supply is weak (e.g., Kashyap and Stein, 2000). The cross-sectional incidence of supply can easily be assessed within our empirical framework by splitting the sample. ${ }^{38}$ We consider two dimensions: leverage and credit ratings.

\section{[TABLE 5]}

We first group firms by book leverage. Leverage quintiles are defined using book debt divided by book assets ("book leverage”). The quintile cut-offs are 0.21, 0.30, 0.39 and 0.49. ${ }^{39}$ Across variables, the low leverage groups have smaller and less significant coefficient estimates. As leverage rises, the effect of loan supply appears larger and more significant (the tightening monetary policy variable is barely significant, even in the high leverage groups, suggesting that this effect is less robust). The sample split by leverage provides evidence for a stronger effect among firms with high leverage.

We next group firms by their credit ratings (S\&P firm credit opinions), into groups of investment grade (BBB- and higher) and non-investment grade (BB+ and lower) firms. ${ }^{40}$ The estimated effect of loan supply tends to be larger and more significant for speculative grade than for investment grade firms (firm quarters, to be exact). For one of the time series variables, the effect is insignificant for investment grade firms, for another, it is insignificant for noninvestment grade firms. The differences across groups are economically meaningful, as well as statistically significant except for monetary policy variable. It appears that weaker firms suffer most when loan supply is tight, by most measures. This might reflect rationing (Stiglitz and

\footnotetext{
${ }^{38}$ We could also allow the coefficient on the time series variable to vary by firm groups, but estimate the regression for the full sample. Splitting by subsample differs in that it allows the coefficient on control variables to vary across groups, but this is not material to our conclusions.

${ }^{39}$ We have also tried year-by-year cut-offs, with similar results.

${ }^{40}$ This sample split leaves out unrated firms. Since the main rating agencies aim to rate all US corporate bond issues, there are virtually no bonds issued by unrated firms. Unrated firms do occasionally receive bank loans, but this leaves us without variation in the left hand side variable for unrated firms.
} 
Weiss 1981) or some other mechanism, but since our empirical design controls for basic demand effects, this cannot simply be a function of different cyclicality of investment opportunities. The weaker firms appear more squeezed on the funding side of their balance sheet.

\section{Further robustness tests}

In this section, we present a number of additional robustness tests. We present these robustness tests in condensed form in Table 6 by presenting only the coefficient of interest. ${ }^{41}$ First, we introduce additional controls capturing various features of new debt. We control for maturity of debt, and for amount of debt raised, and then for both as well as the prevailing yield of debt of similar credit quality as the firm (using corporate ratings to classify). Consistently, the results are similar after the introduction of these additional measures. As can be seen from the first two rows of Table 6, only in one case the coefficient loses statistical significance. Next, we change the conditioning to firms with a bond issued in the last two years or remove the conditioning on past issuance completely, to see whether our results are sensitive to this. This does not appear to change results notably. We also try no filtering, which is equivalent to keeping any bond issuer in the sample indefinitely. This reduces the magnitude and significance of the lending standards variable, but otherwise leaves estimates in the neighborhood of the baseline results. These two tests suggest that while the details of the conditioning on prior issuance (i.e. two vs. five years) is not critical, some conditioning is necessary, most likely to keep firms which had, but no longer have, access to the bond market from contaminating the results.

Our baseline regressions are estimated in the eighty-two quarters from 1990:Q2 to 2010:Q4, a fairly long time period. This raises two concerns. First, the effect of bank-loan supply need not be stable through time, and there is enough time to consider this possibility quantitatively. In particular, we might worry that the 2007-2009 financial crisis somehow differs from normal times. We therefore exclude the last twenty quarters (2006:Q1-2010:Q4) from the sample. This does not have a large impact on the results (the non-performing loans variable has a larger coefficient, while lending standards and stock prices have smaller coefficients, but these are not significant differences). Second, the firm fixed effects are meant to absorb compositional

\footnotetext{
${ }^{41}$ Each line of Table 6 shows the coefficient estimate from a regression, which differs from the baseline regressions in Table 3 as described in the left column.
} 
changes in the pool of firms raising debt. If the time period is too long, firms may change through time, and the firms' fixed effects may not do their job properly. To address this concern, we vary the sample timing and the number of fixed effects.

[TABLE 6]

In the next set of regressions, we allow each firm to have a separate fixed effect for each decade (i.e., 1990:Q2-1999:Q4 and 2000:Q1-2010:Q4). This larger set of fixed effects absorbs more of the variation in the dependent variable, but does not change the coefficients on the time series variables much. Two coefficients are larger in absolute terms, two are smaller, all are significantly different from zero, and none are significantly different from the baseline results (in a statistical sense). We can push this further, of course, by letting the fixed effects apply for even shorter periods. The control for compositional changes becomes even better, but eventually we will run into the limits of identification. The following two lines of Table 6 show results for five and then four year periods. Results remain comparable to the baseline, and generally larger with five year periods, while the bank stock-index has an insignificant coefficient for the four year periods (if we use even shorter periods, not reported, eventually all variables lose significance). The regressions with four year periods contain approximately 4,000 fixed effects and identify only from firms raising both bond and bank debt in the same four-year period, so some loss of significance is perhaps to be expected.

All the tests reported so far have been restricted to term loans and corporate bonds with maturity exceeding one year. However, much bank credit is given in the form of revolving lines, on which firms can draw as needed. Because the amount of outstanding credit is normally much less than the maximum amount available under the revolver, it makes sense to treat credit lines differently. However, excluding credit lines may affect our results if the reduced quantity of bank lending we observe is actually a shift from term loans to credit lines. To test this, we add credit lines and short term market financing, in the form of corporate commercial paper, to the sample. Results are reported in Table $7 .^{42}$

The first line of Table 7 reports base line results from Table 3. The next line uses only commercial paper and credit lines, and the last line combines bonds with commercial paper, and

\footnotetext{
${ }^{42}$ Since commercial paper is often backed by backup commitments by banks, the difference between CP and a credit line may be fairly small to the bank (although high quality issuers can sometimes issue without backup). We follow Kashyap, Stein and Wilcox (1993) in considering these two forms of credit.
} 
credit lines with term loans. Extending the sample to short term credit leads to coefficient estimates that are similar in sign, larger in magnitude in three cases, but smaller and insignificant in two cases (the accounting-based variables). These regressions only have around 2,000 observations after we have excluded firms that never issue CP: only very few firms have access to the commercial paper market. We might expect lower significance due to the limited power in tests that use only short term debt. The mean of the dependent variable is higher, also reflecting the larger role of bank credit in short term financing (see also the two panels of Figure 1 where the same pattern is visible). Despite the low power, three of the five coefficient estimates are significantly different from zero in the short term credit sample. In the full sample, which includes both short and long term credit, the effects estimated earlier are significant, and all the magnitudes are larger than what we estimated for long term credit only. This sample will get identification of firms switching between bonds and term loans, between CP and revolvers, but also firm switching between CP and bank loans (the focus of Kashyap, Stein and Wilcox 1993) and between revolvers and bonds. These strong results on a sample including CP and revolving credit lines confirm that the restriction to long term credit is econometrically conservative and does not bias our results toward finding effects of the time-series variables that we use to proxy for banks’ willingness to lend.

\section{[TABLE 7]}

The robustness results show that our baseline findings are representative of patterns across time periods and credit types, are not particularly sensitive to the number of fixed effects included, and are robust to variations in sample definition and the controls included.

\section{Results: Measurement of bank-loan supply for firms without access to bonds}

\section{A. Out-of-sample predictability}

Our results so far are identified from firms that are able to raise credit in bad times, and, in particular, issue bonds at those times. However the implementation of the measure proposed in this paper is not constrained to the firms with outside financing options. Many firms, for example those that have never issued bonds, will find it hard to substitute to public debt if the supply of bank-loan contracts. If the substitution between private and public debt captures aggregate bankcredit supply, it should predict credit for small firms. This is consistent with the evidence that emerges from Figure 1. In-sample correlation between share of bank debt as a percentage of total 
corporate debt and net percentage of banks tightening lending standard for small firms is -0.42 and -0.39 for medium and large firms. (The correlation is -0.57 for small firms and -0.52 for medium and large firms if we include commercial paper and revolving lines.)

We can further test the relevance of loan and bond substitution as a measure of aggregate loan supply by focusing on the incidence of new bank debt for firms with no access to bond markets. We implement this by estimating the following regression in the sample of Compustat firms that never issue a bond:

$$
P_{j t}=\tilde{\alpha}_{j}+\tilde{\beta} D_{t}+\tilde{\gamma} X_{j t}
$$

where $P_{j t}=1$ if the firm $j$ obtained a bank loan in quarter $t$ and 0 otherwise; $D_{t}$ measures the fraction of firms issuing bank loans, conditional on raising bonds or loans (a non-overlapping sample of firms underlying specification (1), i.e., $D_{t}=\sum_{i} D_{i t} / \sum_{i} 1$ ); as in specification (1), $X_{j t}$ is a set of controls, specific to the firm $j .{ }^{43}$

Results are presented in Table 8. The dependent variable's mean is low, only 0.012, so coefficients magnitudes should be smaller than in the base line regression presented in Table 3. Of the five time-series variables used in the earlier test, three predict probability that the firm will get bank loans in this sample (Table 8, columns 1 through 4). The coefficients are also economically large compared to the mean of the dependent variable. Notice that the measure of tightening in lending standards — as discussed earlier, the measure most frequently used as an indicator of credit supply-is statistically insignificant. ${ }^{44}$ Although overall results are consistent with the loan supply interpretation - e.g., increase in non-performing loans is associated with a lower likelihood of a firm getting a loan - this is not a stringent test because some of the correlation might be driven by variation in the demand for credit.

The focus of Table 8 is on columns five and six where we include the fraction of bank loans in external credit as an explanatory variable. (If there are 100 firms issuing debt in a given quarter and 5 of them issue loans, Loan-to-bond substitution is 0.05.) By construction, variation

\footnotetext{
${ }^{43}$ In the reported results we use the sample of substituting firms (explanatory variable) that is not are not constrained to firms that issued bonds in the last five years.

${ }^{44}$ The survey from which this measure is taken asks separate questions for borrowers of different sizes. We continue to use the survey data on tightening in lending standards for medium and large firms because our sample only includes firms with Compustat data (i.e., these firms are relatively large). However, the time-series correlation between the tightening in lending standards to small and that to medium and large firms is 0.97 so this choice is unlikely to matter.
} 
in this measure picks up variation in credit supply. As expected, the coefficient is positive and significant. The coefficient estimate implies that a one standard deviation increase in the ratio (9.4 percentage points) predicts an increase in the probability of an unrated firm receiving a bank loan in a given quarter by $0.2 \%$, i.e., a $17 \%$ increase over the mean probability. The variable holds up remarkably well in a "horse race” with the other time-series variables. The bank stockindex remain significant, whereas the tightening in loan standards variable becomes significant but with a positive coefficient. This shows the strong out-of-sample predictive power of the Loan-bond substitution variable, suggesting that the choice between bond and loan financing for the set of unconstrained firms is indeed a useful indicator of banks' aggregate willingness to lend.

\section{[TABLE 8]}

We must acknowledge that in generalizing the substitution between bank and bond debt as a measure of loan supply, we must be careful in interpreting the magnitudes. In recessions, the shift in bank credit supply for smaller firms is likely to be larger than for the firms that can freely substitute between bonds and loans (and in that sense, we pick the lower bound of the loan supply shift). While this is a limitation, the substitution variable (based on firms that can substitute) constitutes a substantial improvement over existing measures of bank-loan supply in a time-series context. ${ }^{45}$

\section{B. Real effects}

By studying firm substitution between different forms of external financing, we have argued that we get an indication of supply, which is not contaminated with demand factors. However, an ultimate question is whether shift in loan supply has real effects, and, more specifically, if we can identify those effects in the time-series context. In our last set of results we study this question, by examining firm capital expenditures. An important caveat to these results is that we cannot rely on the same revealed preference argument we use in the financing regression, so that

\footnotetext{
${ }^{45}$ A further caveat here is that the identification is less clear here than for our main results. The main results are about identifying as well as quantifying loan supply, but the out of sample investment results are about measurement more than clean identification. We cannot rule out that the small, constrained firms have credit demand that is correlated with the loan supply experienced by large firm. The finding here is that our bond/bank mix variable is a better time series measure than the alternative measures, in the sense of being more strongly correlated with credit, and more cleanly derived from measurement of loan supply.
} 
loan demand (and, closely related, firms desire to invest) may not be completely ruled out by controls and fixed effects.

Table 9 presents a reduced form of the effect of bank credit supply on firms' investments. The focus is on the independent variable measuring aggregate loan to bond substitution $\left(D_{t}\right)$. $^{46}$ The economic signs are as predicted if loan supply impact investment decisions; a lower share of loans as a fraction of total debt (a contraction in the credit supply) is associated with lower investments. The results are statistically significant for the set of firms with access to both bond and loan markets. We next examine firms which have not previously issued bonds. For these firms, which lack access to the bond market, the coefficient estimate is again positive, and somewhat larger. This result is consistent with the earlier argument that bonds and loans are close substitutes for the firms with access to both forms of debt financing, so that firms with bond market access are less affected by bank-loan supply.

The last two columns in Table 9 focus on a sub-sample of financially constrained firms. We report results conditioning on above industry-median leverage (high leverage) and below industry-median stock-market valuation (low valuation) as proxies for financial constraints in general and specifically limited access to the equity market in combination with proven appetite for debt. This set of Compustat firms likely resembles non-Compustat firms better than the overall sample, and in that sense, this result may be suggestive of the business cycle effect of loan supply on investment for small firms generally. For this set of more constrained firms, the fraction of firms issuing loans in the overall flow of corporate debt is a significant predictor of investment activity. Again, the point estimate is higher than before (although the difference is not statistically significant).Thus, consistent with theory, these findings indicate that bank-credit supply is an important determinant of the real activity for bank-dependent firms.

\section{[TABLE 9]}

\section{Conclusions}

Theory predicts that credit supply may be an important factor in explaining the evolution of the business cycle. The existing empirical literature has uncovered several examples

\footnotetext{
${ }^{46}$ To the extent that we think this variable acts on investment through the loan supply, this regression is akin to a reduced form regression, with the omitted intermediary variable being financing. As the results in Table 8 illustrate, the first stage of this type of regression produces strong results.
} 
consistent with the economic role of the credit supply, but largely in cross-sectional settings or using isolated events. Tests using natural experiments or instruments to identify effects of the credit supply have limited out-of-sample applicability, and may not capture how credit supply moves in business downturns. The fact that there was a contraction in credit supply following the burst of the Japanese bubble in the early 1990s and after the 1998 Russian debt crisis can tell us that firms suffer when their lenders are troubled, but provides little guidance about how bank lending aggravates the business cycles such as the 2008 downturn, or if banks' reluctance to lend delayed the recovery in 2010. On the other hand, work that uses bank-level cross-sectional variation to identify the credit-supply effect in a time series admits other interpretations. In this paper we bring new evidence to bear on the question of bank lending in the business cycle. This evidence provides a sharper test of whether credit supply matters in a time series setting.

Rather than bank-level variation in loan issuance, we study firms' choice between bank and public debt. Our focus is on large, rated firms for which these two forms of financing can be considered close substitutes. There are time-series measures of bank lending, but they may confound demand and supply. For example, tighter lending standards based on the Federal Reserve Senior Loan Officer Opinion Survey on Bank Lending Practices could be correlated with firms' demand for credit. Thus, we need to control for demand, and our method for doing that is one of the principal contribution of this paper. The intuition for our methodology is simple: by restricting the sample to firms that receive new debt financing in a given quarter, we are able to isolate the demand effect. Because sample firms receive some form of credit, we know that they demanded new external financing. Conditional on getting financing if a firm issues bonds when credit standards are tightening (relative to its typical sourcing of debt), we interpret this as a contraction in bank credit supply. Using firm-level data we can control for firm-level effects, which rules out any explanation based on shifts in the composition of demand at the aggregate level. We also rule out a shift in bond supply and relative shift in demand for bonds as alternative explanations of our findings.

By design, we focus on the least financially constrained firms in the economy, however, the implementation of our measure in not constrained to these firms. We validate the loan-tobond substitution effect for large firms as a predictor variable in the out-of-sample context for overall contraction in credit for small and non-rated firms. As expected, our results are a strong predictor of overall contraction in credit for firms that cannot substitute into bonds. 


\section{References}

Angrist, J. and J. Pischke, 2009, Mostly Harmless Econometrics, Princeton University Press.

Ashcraft, A., 2005, “Are Banks Really Special? New Evidence from the FDIC-Induced Failure of Healthy Banks,” American Economic Review 95, 1712-1730.

Barakchian, M., and Cristopher Crowe, 2010, “Monetary Policy Matters: New Evidence Based on a New Shock Measure,” IMF Working Paper No. 10/230.

Becker, B, 2007, “Geographical Segmentation of US Capital Markets”, Journal of Financial Economics 85, 151-187.

Bernanke, B., and M. Gertler, 1989, “Agency Costs, Net Worth, and Business Fluctuations”, The American Economic Review 79, 14-31.

Bolton, P. and X. Freixas, 1999, “Equity, Bonds and Bank Debt: Capital Structure and Financial Market Equilibrium under Asymmetric Information”, Journal of Political Economy 108, 324-351.

Bolton, P., and D. Scharfstein, 1996, “Optimal Debt Structure and the Number of Creditors”, Journal of Political Economy 104, 1-25.

Chava, Sudheer and Amiyatosh Purnanandam, 2011, "The Effect of Banking Crisis on BankDependent Borrowers”, Journal of Financial Economics 99, 116-135.

Chemmanur, T., and P.Fulghieri, 1994, "Reputation, Renegotiation, and the Choice between Bank Loans and Publically Traded Debt,” Review of Financial Studies 7, 475-506.

Diamond, D., 1991, “Monitoring and Reputation: The Choice between Bank Loans and Directly Placed Debt,” Journal of Political Economy 99, 688-721.

Diamond, D., and R. Rajan, 2005, “Liquidity Risk, Liquidity Creation, and Financial Fragility: A Theory of Banking,” Journal of Political Economy 109, 287-327.

Estrella, A., and G. Hardouvelis, 1991, “The Term Structure as a Predictor of Real Economic Activity,” Journal of Finance 46, 555-576. 
Fama, E., and K. French, 1997, “Industry costs of equity,” Journal of Financial Economics 43, 153-193.

Faulkender, M., and M. Petersen, 2005, “Does the Source of Capital Affect Capital Structure?” Review of Financial Studies 19, 45-79.

Hale, G., and J. Santos, 2008, “The decision to first enter the public bond market: The role of firm reputation, funding choices, and bank relationships”, Journal of Banking and Finance 32, 1928-1940.

Hale, G., and J. Santos, 2009, “Do banks price their informational monopoly?”, Journal of Financial Economics 93, 185-206.

Holmström, B., and J. Tirole, 1997, “Financial Intermediation, Loanable Funds, and the Real Sector”, Quarterly Journal of Economics 112, 663-691.

Ivashina, V., 2009, “Asymmetric Information Effects on Loan Spreads”, Journal of Financial Economics, 92, 300-319.

Ivashina, V., and D. Scharfstein, 2010, “Bank Lending in the Financial Crisis of 2008”, Journal of Financial Economics 97, 319-338.

Jensen, M. and W. Meckling, 1976, “Theory of the firm: Managerial behavior, agency costs, and capital structure,” Journal of Financial Economics.

Johnson,S., 1997, “An Empirical Analysis of the Determinants of Corporate Debt Ownership Structure”, Journal of Financial and Quantitative Analysis, 32(1).

Kashyap, A., O. Lamont, J. Stein, 1994, “Credit Conditions and the Cyclical Behavior of Inventories”, Quarterly Journal of Economics 109, 565-592.

Kashyap, A. and J. Stein, 2000, “What Do A Million Observations on Banks Say About the Transmission of Monetary Policy?”, American Economic Review 90, 407-28.

Kashyap, A., J. Stein, and D Wilcox, 1993, “Monetary Policy and Credit Conditions: Evidence from the Composition of External Financ”, American Economic Review 83(1), 221-56. 
Kiyotaki, N., and J. Moore, 1997, “Credit Cycles”, Journal of Political Economy 105, 211-248.

Koijen, R., O. Van Hemert, and S. Van Nieuwerburgh, 2009, “Mortgage Timing”, Journal of Financial Economics 93, 292-324.

Leary, M., 2009, “Bank Loan Supply, Lender Choice, and Corporate Capital Structure,” Journal of Finance 64(3), 1143-1185.

Myers, S., 1977, “Determinants of Corporate Borrowing”, Journal of Financial Economic 5, 147175.

Peek, J. and E. Rosengren, 2000, “Collateral Damage: Effects of the Japanese Bank Crisis on Real Activity in the United States,” American Economic Review 90, 30-45.

Rajan, R.G., 1992,”Insiders and Outsiders: The Choice between Informed and Arms-Length Debt,” Journal of Finance 47, 1367-1400.

Romer, C., and D. Romer, 2004, "A New Measure of Monetary Shocks: Derivation and Implications,” American Economic Review 94, 1055-1084.

Santos, J. and A. Winton, 2011, "Bank Loans, Bonds, and Information Monopolies Across the Business Cycle,” Journal of Finance, forthcoming.

Stiglitz, J. and A. Weiss, 1981, “Credit Rationing in Markets with Imperfect Information”, American Economic Review, 71(3), June, 393-410.

Taylor, J., 1993. “Discretion versus Policy Rules in Practice,” Carnegie-Rochester Conference Series of Public Policy, 39, 195-214. 
Figure 1

Share of bank debt as a percentage of total corporate debt financing

The graph plots number of firms issuing bank loans as a fraction of all firms issuing debt in a given quarter (Bank debt/Total debt). Data on tightening in lending standards comes from Federal Reserve Senior Loan Officer Opinion Survey on Bank Lending Practices and correspond to the net percentage of medium and large lenders tightening credit standard for commercial and industrial loans. The horizontal line corresponds to the historic average of bank debt as a percentage of total corporate debt calculation over 1990-2007 period excluding NBER recessions.

Panel A: Excluding commercial paper and revolving lines

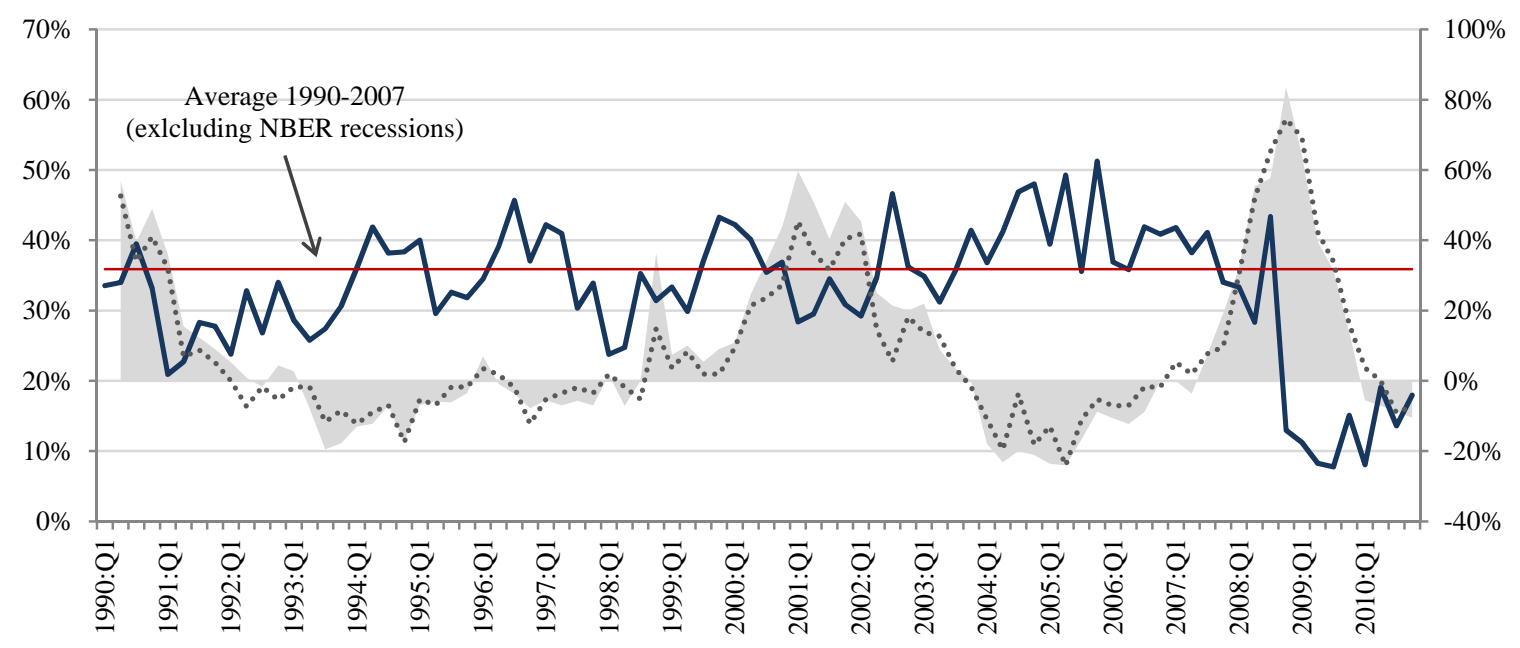

\footnotetext{
Net \% of banks tightening lending standards, medium and large firms (secondary axis)

Bank debt/Total debt (\%)

........ Net \% of banks tightening lending standards, small firms (secondary axis)
}

Panel B: Including commercial paper and revolving lines

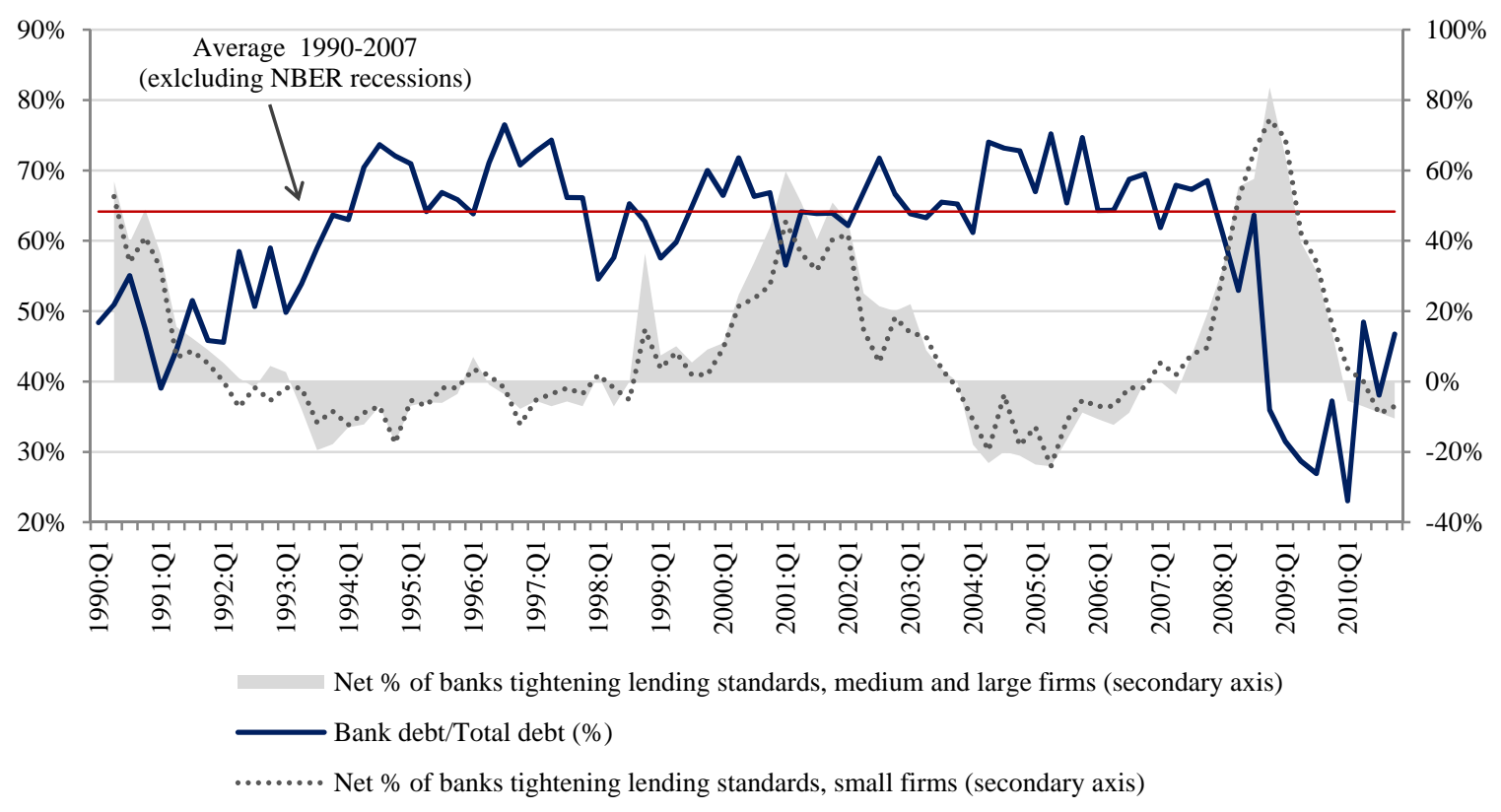




\section{Figure 2}

Corporate credit growth: Loans vs. Bonds, 1953-2010

Figure 2 is compiled from quarterly United States Flow of Funds Accounts data (1953:Q1 -2010:Q4.) Each series corresponds to a four quarter rolling-window growth in nonfarm, nonfinancial corporate debt stock (Flow of Funds). Bank and other loans is the sum of Other Loans and Advances and Bank Loans Not Elsewhere Classified. Commercial paper and corporate bonds includes Commercial Paper and Corporate Bonds. Shaded areas indicate NBER recession periods. Dashed vertical lines indicate exogenous shifts in bank credit supply documented by the existing literature: (i) 1961 credit expansion following emergence of the market for certificate deposits (Leary, 2010); (ii) 1966 Credit Crunch (Leary, 2010); (iii) 1990 credit contraction following the burst of the Japanese real estate bubble (Peek and Rosengren, 2000); and (iv) 1998 credit contraction following the Russian debt crisis (Chava and Purnanandam, 2011).

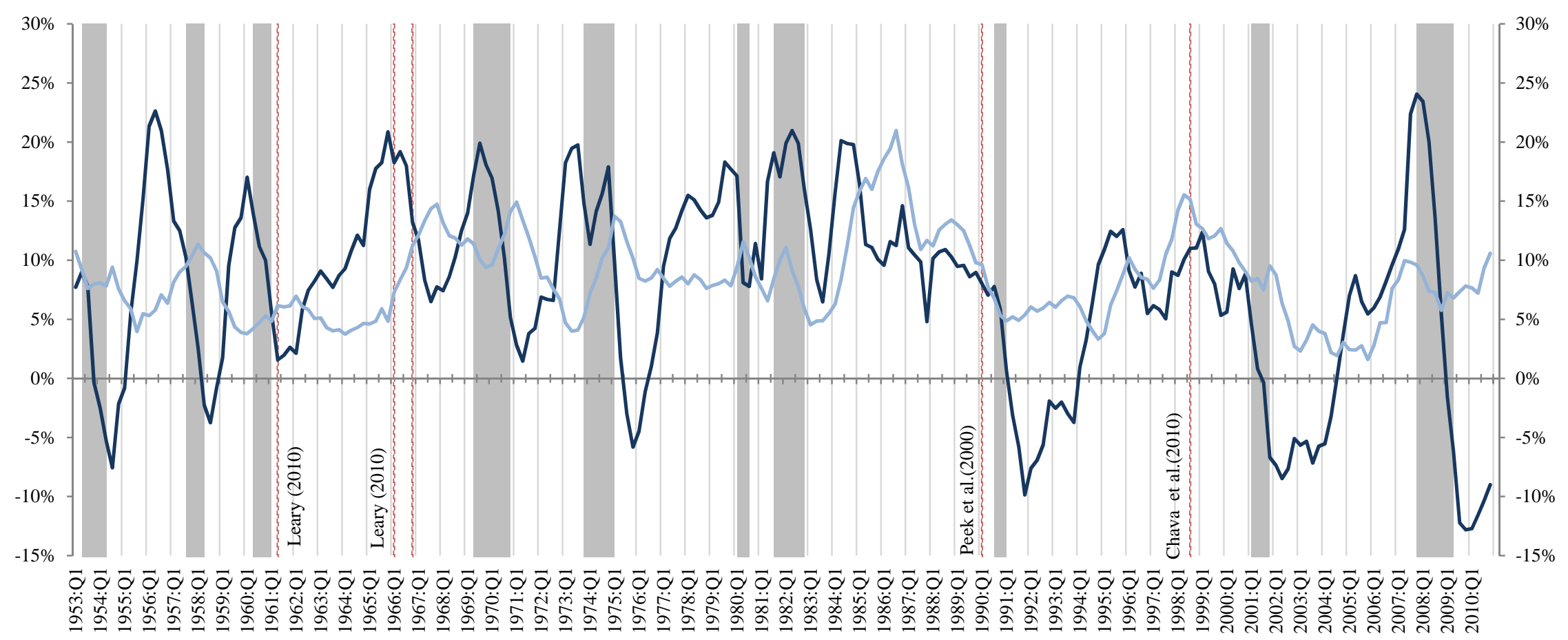

— Bank and other loans $\quad$ C Commercial paper and corporate bonds 


\section{Table 1 \\ Firm Level Variables}

This table summarized statistics from the firm-level quarterly panel, covering the 1990:Q2 to 2010:Q4 period. Debt financing data is tabulated for observations with data on control variables. Firm controls are the log of assets (lagged), the log of property, plant and equipment (lagged), the return on assets (operating income before depreciation divided by previous quarter's assets), market-to-book ratio (lagged), one year lagged return to the end of the previous quarter, and a dummy indicating whether a firm pays a dividend in the current quarter. GDP growth is real per capita growth, seasonally adjusted. Data on tightening in lending standards comes from Federal Reserve Senior Loan Officer Opinion Survey on Bank Lending Practices. The series corresponds to the net percentage of domestic respondents tightening standard for commercial and industrial (C\&I) loans to large and medium-sized firms. Non-performing loans (\% of total loans) and loan allowances (\% of total loans) were compiled from Call Reports and correspond to assets-weighted averages. Bank stock-index is the logarithm of the level of the marketadjusted price for banks (industry \#11) available from Kenneth French's data library. Monetary policy is based on the federal funds rate deviation from the target level as specified by Taylor-rule. In Panel C, correlations are calculated in times series data.

Panel A: Frequency of new debt finance

\begin{tabular}{lrr}
\hline Observations (firm-quarter): & \\
Full sample & 223,084 & $100.0 \%$ \\
With no new debt & 210,857 & $94.5 \%$ \\
Excluding commercial paper and revolving credit lines: & \\
With new debt & 12,227 & $5.5 \%$ \\
With new bank debt & 3,862 & $1.7 \%$ \\
With new bond debt & 8,791 & $3.9 \%$ \\
With only one kind of new debt & 11,801 & $5.3 \%$ \\
Including commercial paper and revolving credit lines: & & \\
With new debt & 21,053 & $9.4 \%$ \\
With new bank debt & 9,458 & $4.2 \%$ \\
With new bond debt & 13,237 & $5.9 \%$ \\
\hline
\end{tabular}

Panel B: Firm level control variables (sample with only one kind of new debt)

\begin{tabular}{lcccccc}
\hline \multicolumn{1}{c}{ Variable name } & Observations & Mean & Std. Dev. & $10^{\text {th }} \%$ & Median & $90^{\text {th }} \%$ \\
\hline Log (Assets) & 11,801 & 7.372 & 1.986 & 4.631 & 7.482 & 9.912 \\
Log (PP\&E) & 11,801 & 6.188 & 2.370 & 2.869 & 6.472 & 9.089 \\
ROA & 11,801 & 0.032 & 0.036 & 0.007 & 0.033 & 0.064 \\
Market-to-book & 11,801 & 1.491 & 0.662 & 0.942 & 1.294 & 2.286 \\
Lagged 4y return & 11,801 & 0.017 & 0.583 & -0.573 & 0.038 & 0.551 \\
Leverage & 11,801 & 0.326 & 0.181 & 0.083 & 0.321 & 0.552 \\
Dividend payer & 11,801 & 0.526 & 0.499 & 0 & 1 & 1 \\
\hline
\end{tabular}




\section{Table 1-continued}

Panel C: Time series variables (1990:Q2-2010:Q4)

\begin{tabular}{lrrrrr}
\hline \multicolumn{1}{c}{ Variable name } & Mean & Std. Dev. & $10^{\text {th }} \%$ & Median & $90^{\text {th }} \%$ \\
\hline Tightening in lending standards & $9.5 \%$ & $24.4 \%$ & $-17.4 \%$ & $1.8 \%$ & $48.9 \%$ \\
Non-performing loans (starts in 1994:Q1) & $1.9 \%$ & $3.3 \%$ & $0.4 \%$ & $0.7 \%$ & $8.2 \%$ \\
Loan allowances (starts in 1994:Q1) & $1.8 \%$ & $0.7 \%$ & $1.1 \%$ & $1.7 \%$ & $3.3 \%$ \\
Bank stock-index & 1.89 & 0.29 & 1.52 & 1.90 & 2.30 \\
Monetary policy & -0.009 & 0.016 & -0.032 & -0.008 & 0.111 \\
\hline
\end{tabular}

Panel D: Time series variables correlations

\begin{tabular}{llllll}
\hline \multicolumn{1}{c}{ Variable name } & \multicolumn{1}{c}{$(1)$} & \multicolumn{1}{c}{$(2)$} & \multicolumn{1}{c}{ (3) } & \multicolumn{1}{c}{ (4) } \\
\hline (1) & Tightening in lending standards & 1 & & & \\
(2) & Non-performing loans (starts in 1994:Q1) & 0.173 & 1 & & \\
(3) & Loan allowances (starts in 1994:Q1) & 0.153 & $0.849^{* * *}$ & 1 & \\
(4) & Bank stock-index & $-0.227^{* *}$ & $-0.555^{* * *}$ & $-0.708^{* * *}$ & 1 \\
(5) & Monetary policy & -0.014 & 0.088 & 0.117 & $-0.312^{* * *}$ \\
\hline
\end{tabular}




\section{Table 2}

\section{Growth of Nonfarm, Nonfinancial Corporate Debt Stock}

The data is compiled from the quarterly Flow of Funds data. Bank debt is the sum of Other Loans and Advances and Bank Loans Not Elsewhere Classified. Market debt is the sum of Credit Commercial Paper Issued by Nonfinancial Firms and Corporate Bonds. The data covers 234 quarters from 1952:Q4 to2011:Q1. Growth rates are real four quarter log growth rates (net of the log change in the consumer price index). Panel A reports distribution of corporate credit Panel B, regressions of current credit growth on lagged credit growth and controls are presented. Any quarter containing a month classified as a recession month by NBER is classified as a recession. Errors are heteroskedasticity-robust. ${ }^{* * *},{ }^{* *},{ }^{*}$ indicate statistical significance at $1 \%, 5 \%$ and $10 \%$ level, respectively.

Panel A: Summary statistics

\begin{tabular}{lll}
\hline Rolling 4Q growth rate, real & Public debt & Bank debt \\
\hline Mean & $6.83 \%$ & $6.17 \%$ \\
Std. Dev. & $3.58 \%$ & $7.80 \%$ \\
Min & $0.13 \%$ & $-13.94 \%$ \\
$10^{\text {th } \%}$ & $2.91 \%$ & $-6.29 \%$ \\
Median & $6.30 \%$ & $7.37 \%$ \\
$90^{\text {th }} \%$ & $11.49 \%$ & $16.30 \%$ \\
Max & $20.21 \%$ & $23.29 \%$ \\
Quarters with negative growth (fraction) & 0 (or 0\%) & 51 (or 20.8\%) \\
Correlation with real GDP growth & 0.032 & $0.228 * * *$ \\
\hline
\end{tabular}

Panel B: Regression of real growth on lagged growth, real GDP and recessions

\begin{tabular}{lll}
\hline & Public debt & Bank debt \\
\hline Lagged growth (previous quarter) & $0.940^{* * *}$ & $0.927^{* * *}$ \\
& $(0.026)$ & $(0.023)$ \\
NBER recession indicator & 0.002 & -0.004 \\
& $(0.002)$ & $(0.006)$ \\
GDP growth (real, 4 quarter) & -0.074 & $1.169^{* * *}$ \\
& $(0.082)$ & $(0.200)$ \\
$R$-squared & 0.885 & 0.885 \\
Observations & 233 & 233 \\
\hline
\end{tabular}




\section{Table 3}

\section{Within-Firm Evidence on Loan vs. Bond Choice}

Each observation in the sample corresponds to a new issue of bank or public debt. If in a given quarter a firm did not have a new loan or bond issue, it will not be included in the sample. In this table, observations are excluded when a firm has not issued a bond in the last five years. The dependent variable is a dummy equal to 1 if the firm received a bank loan in that quarter and 0 otherwise. The table reports results of the linear regressions for the period 1990:Q2 to 2010:Q4. Data on tightening in lending standards comes from Federal Reserve Senior Loan Officer Opinion Survey on Bank Lending Practices. The series corresponds to the net percentage of domestic respondents tightening standard for commercial and industrial (C\&I) loans to large and medium-sized firms. Non-performing loans and loan allowances (both as a fraction of total loans) were compiled from Call Reports for big banks and correspond to assets-weighted averages. Both data series start in 1994:Q1, and as a result, the sample is slightly smaller for these specifications. Bank stock-index is the logarithm of the level of the market-adjusted price for banks (industry \#11) available from Kenneth French's data library. Monetary policy is based on the federal funds rate deviation from the target level as specified by Taylor-rule. Firm controls are the log of assets (lagged), the log of property, plant and equipment (lagged), the return on assets (operating income before depreciation divided by previous quarter's assets), one year lagged return to the end of the previous quarter, leverage (long term debt over assets) and a dummy indicating whether a firm pays dividends in the current quarter, respectively. Errors are heteroskedasticity-robust and clustered by quarter. $* * *, * *, *$ indicate statistical significance at $1 \%, 5 \%$ and $10 \%$ level, respectively.

\begin{tabular}{|c|c|c|c|c|c|}
\hline \multicolumn{6}{|c|}{ Dependent variable: Dummy equal 1 if the issue is a loan, 0 if the issue is a bond } \\
\hline Dependent variable mean: & $\begin{array}{l}0.135 \\
(1)\end{array}$ & $\begin{array}{l}0.148 \\
(2)\end{array}$ & $\begin{array}{l}0.148 \\
(3)\end{array}$ & $\begin{array}{l}0.135 \\
(4)\end{array}$ & $\begin{array}{l}0.135 \\
(5)\end{array}$ \\
\hline Tightening in lending standards & $\begin{array}{l}-0.059 * * \\
(0.026)\end{array}$ & & & & \\
\hline Non-performing loans & & $\begin{array}{l}-1.030^{* * *} \\
(0.160)\end{array}$ & & & \\
\hline Loan allowances & & & $\begin{array}{l}-5.122^{* * *} \\
(0.854)\end{array}$ & & \\
\hline Bank stock-index & & & & $\begin{array}{l}0.108 * * * \\
(0.021)\end{array}$ & \\
\hline Monetary policy & & & & & $\begin{array}{l}-1.617^{* * *} \\
(0.571)\end{array}$ \\
\hline Log (Assets) & $\begin{array}{l}0.039 * \\
(0.021)\end{array}$ & $\begin{array}{l}0.049 * \\
(0.026)\end{array}$ & $\begin{array}{l}0.043^{*} \\
(0.025)\end{array}$ & $\begin{array}{l}0.022 \\
(0.021)\end{array}$ & $\begin{array}{l}0.025 \\
(0.021)\end{array}$ \\
\hline Log (PP\&E) & $\begin{array}{l}-0.017 \\
(0.019)\end{array}$ & $\begin{array}{l}-0.018 \\
(0.022)\end{array}$ & $\begin{array}{l}-0.016 \\
(0.021)\end{array}$ & $\begin{array}{l}-0.011 \\
(0.019)\end{array}$ & $\begin{array}{l}-0.012 \\
(0.019)\end{array}$ \\
\hline ROA & $\begin{array}{l}-0.375 \\
(0.231)\end{array}$ & $\begin{array}{l}-0.394 \\
(0.245)\end{array}$ & $\begin{array}{l}-0.351 \\
(0.250)\end{array}$ & $\begin{array}{l}-0.353 \\
(0.230)\end{array}$ & $\begin{array}{l}-0.345 \\
(0.229)\end{array}$ \\
\hline Market-to-book & $\begin{array}{l}-0.026^{* *} \\
(0.013)\end{array}$ & $\begin{array}{l}-0.040^{* *} \\
(0.016)\end{array}$ & $\begin{array}{l}-0.047^{* * *} \\
(0.015)\end{array}$ & $\begin{array}{l}-0.039 * * \\
(0.013)\end{array}$ & $\begin{array}{l}-0.025^{*} \\
(0.013)\end{array}$ \\
\hline Lagged return & $\begin{array}{l}-0.035^{* * *} \\
(0.012)\end{array}$ & $\begin{array}{l}-0.037 * * * \\
(0.012)\end{array}$ & $\begin{array}{l}-0.033^{* * *} \\
(0.012)\end{array}$ & $\begin{array}{l}-0.032^{* * *} \\
(0.011)\end{array}$ & $\begin{array}{l}-0.031^{* * *} \\
(0.012)\end{array}$ \\
\hline Leverage & $\begin{array}{l}-0.037 \\
(0.049)\end{array}$ & $\begin{array}{l}-0.073 \\
(0.057)\end{array}$ & $\begin{array}{l}-0.071 \\
(0.058)\end{array}$ & $\begin{array}{l}-0.043 \\
(0.049)\end{array}$ & $\begin{array}{l}0.040 \\
(0.047)\end{array}$ \\
\hline Dividend payer & $\begin{array}{l}-0.096^{* * *} \\
(0.024)\end{array}$ & $\begin{array}{l}-0.102^{* * * *} \\
(0.0288)\end{array}$ & $\begin{array}{l}-0.100^{* * *} \\
(0.028)\end{array}$ & $\begin{array}{l}-0.086^{* * *} \\
(0.024)\end{array}$ & $\begin{array}{l}-0.088^{* * *} \\
(0.024)\end{array}$ \\
\hline Firm fixed effects (Obs.) & Yes $(2,288)$ & Yes $(2,158)$ & Yes $(2,158)$ & Yes $(2,288)$ & Yes(2,288) \\
\hline Clusters (quarter) & 83 & 68 & 68 & 83 & 83 \\
\hline$R$-squared & 0.39 & 0.40 & 0.40 & 0.39 & 0.39 \\
\hline Observations & 9,670 & 8,156 & 8,156 & 9,670 & 9,670 \\
\hline
\end{tabular}




\section{Table 4}

Correlations between Relative Cost of Corporate Loans vs. Bonds and Indicators of Credit Conditions

The relative cost of corporate loans vs. bonds is calculated as a ratio between all-fees-in spread paid over LIBOR on corporate term loans scaled by the difference between bond yield to maturity and LIBOR swap rate with the same maturity as the underlying bonds. Reported numbers are computed using quarterly averages for new loan and bond issues with 3 to 10 year maturity matched by credit rating. Loan-to-bond substitution is defined as the fraction of firms which used bank credit among those firms that receive only one type of financing in a given quarter. The rest of the time series variables are defined in Table 3 . Data is quarterly and corresponds to the period between 1990:Q2 and second 2010:Q4.

\begin{tabular}{|c|c|c|c|c|c|c|c|c|}
\hline & \multicolumn{8}{|c|}{ Loan spread paid over LIBOR/(Bond yield - LIBOR swap rate) } \\
\hline & A & & $\mathrm{BBB}$ & & $\mathrm{BB}$ & & $\mathrm{B}$ & \\
\hline & Corr. & $p$-value & Corr. & $p$-value & Corr. & $p$-value & Corr. & $p$-value \\
\hline & \multicolumn{8}{|c|}{ Full sample (1990:Q2-2010:Q4) } \\
\hline \multicolumn{9}{|l|}{ Proposed measure: } \\
\hline Loan-to -bond substitution (excluding CP and revolving lines) & -0.108 & $(0.42)$ & 0.090 & $(0.42)$ & 0.224 & $(0.04)$ & 0.087 & $(0.45)$ \\
\hline Loan-to-bond substitution (including CP and revolving lines) & -0.136 & $(0.31)$ & 0.192 & $(0.08)$ & 0.197 & $(0.08)$ & 0.012 & $(0.91)$ \\
\hline \multicolumn{9}{|l|}{ Standard time-series measure: } \\
\hline Tightening in lending standards, medium and large firms & 0.045 & $(0.73)$ & -0.423 & $(0.00)$ & -0.103 & $(0.36)$ & 0.075 & $(0.51)$ \\
\hline Tightening in lending standards, small firms & 0.029 & $(0.83)$ & -0.376 & $(0.00)$ & -0.100 & $(0.38)$ & 0.041 & $(0.73)$ \\
\hline Non-performing loans & 0.011 & $(0.94)$ & -0.070 & $(0.55)$ & -0.247 & $(0.03)$ & 0.068 & $(0.57)$ \\
\hline Loan allowances & 0.003 & $(0.98)$ & -0.059 & $(0.60)$ & -0.384 & $(0.00)$ & -0.219 & $(0.06)$ \\
\hline Bank stock-index & 0.093 & $(0.49)$ & 0.101 & $(0.37)$ & 0.090 & $(0.43)$ & 0.230 & $(0.04)$ \\
\hline \multirow[t]{2}{*}{ Tightening monetary policy } & -0.112 & $(0.40)$ & 0.214 & $(0.05)$ & 0.082 & $(0.47)$ & 0.025 & $(0.83)$ \\
\hline & \multicolumn{8}{|c|}{ NBER recession periods } \\
\hline \multicolumn{9}{|l|}{ Proposed measure: } \\
\hline Loan-to -bond substitution (excluding CP and revolving lines) & -0.124 & $(0.72)$ & 0.447 & $(0.11)$ & 0.419 & $(0.15)$ & 0.156 & $(0.67)$ \\
\hline Loan-to-bond substitution (including CP and revolving lines) & -0.146 & $(0.67)$ & 0.203 & $(0.49)$ & 0.191 & $(0.53)$ & 0.344 & $(0.33)$ \\
\hline \multicolumn{9}{|l|}{ Standard time-series measure: } \\
\hline Tightening in lending standards, medium and large firms & -0.427 & $(0.19)$ & -0.090 & $(0.76)$ & -0.445 & $(0.13)$ & -0.359 & $(0.31)$ \\
\hline Tightening in lending standards, small firms & -0.402 & $(0.22)$ & -0.029 & $(0.92)$ & -0.493 & $(0.09)$ & -0.623 & $(0.05)$ \\
\hline Non-performing loans & -0.428 & $(0.29)$ & -0.033 & $(0.92)$ & -0.464 & $(0.15)$ & -0.286 & $(0.42)$ \\
\hline Loan allowances & 0.015 & $(0.97)$ & 0.005 & $(0.99)$ & -0.183 & $(0.55)$ & -0.427 & $(0.22)$ \\
\hline Bank stock-index & -0.242 & $(0.47)$ & -0.128 & $(0.66)$ & -0.429 & $(0.14)$ & 0.653 & $(0.04)$ \\
\hline Tightening monetary policy & -0.007 & $(0.98)$ & -0.059 & $(0.84)$ & -0.027 & $(0.93)$ & 0.234 & $(0.51)$ \\
\hline
\end{tabular}




\section{Table 5}

\section{Loan vs. Bond Choice: By Firms’ Characteristics}

This table re-examines results in Table 3 for different subsamples. The specifications are exactly the same as in Table 3, but for compactness of presentation we only report coefficients for the main explanatory variables - tightening in lending standards from Senior Loan Officer Opinion Survey, non-performing loans and loan allowances (both as a fraction of total loans) were compiled from Call Reports, the logarithm of bank stock-index and monetary policy shocks calculated using the federal funds rate deviation from the target level as specified by Taylor-rule. As in Table 3, regressions correspond to the choices of bank loan vs. bond finance over the period 1990:Q2 to 2010:Q2. Each observation is a firm-quarter where the firm issued bonds, received a new loan, or both. The dependent variable is a dummy equal to 1 if the firm received a bank loan in that quarter and 0 otherwise. Errors are heteroskedasticity-robust and clustered by quarter. $* * *$, **, * indicate statistical significance at $1 \%, 5 \%$ and $10 \%$ level, respectively.

\begin{tabular}{|c|c|c|c|c|c|}
\hline \multirow[b]{2}{*}{ Explanatory variable: } & \multicolumn{5}{|c|}{ Dependent variable: Dummy equal 1 if the issue is a loan, 0 if the issue is a bond } \\
\hline & $\begin{array}{c}\text { Tightening in lending } \\
\text { standards }\end{array}$ & Non-performing loans & Loan allowances & Bank stock-index & $\begin{array}{c}\text { Tightening } \\
\text { monetary policy }\end{array}$ \\
\hline Benchmark (Table 3) & $-0.059 * *$ & $-1.030 * * *$ & $-5.122 * * *$ & $0.108 * * *$ & $-1.617 * * *$ \\
\hline Yield ratio (by rating category) & $-0.079 * * *$ & $-1.258 * * *$ & $-7.022 * * *$ & $0.121^{* * *}$ & $-1.333 * *$ \\
\hline Single-segment firms only & $-0.067 * *$ & $-0.935 * * *$ & $-5.150 * * *$ & $0.112 * * *$ & $-1.507 * *$ \\
\hline \multicolumn{6}{|l|}{ Book leverage: } \\
\hline Bottom quintile & -0.032 & $-0.684^{* *}$ & -1.767 & $0.068 *$ & -0.939 \\
\hline Second quintile & -0.022 & $-0.968 * * *$ & $-4.610 * *$ & 0.042 & -0.925 \\
\hline Middle quintile & -0.023 & $-0.936 * * *$ & $-4.822 * * *$ & $0.095^{* *}$ & $-1.543 * *$ \\
\hline Third quintile & -0.067 & $-1.412 * * *$ & $-7.664 * * *$ & $0.186 * * *$ & -1.556 \\
\hline Top quintile & $-0.150 * *$ & $-1.606 * * *$ & $-8.766 * * *$ & $0.194 * * *$ & -1.347 \\
\hline \multicolumn{6}{|l|}{ Credit rating: } \\
\hline Investment grade & -0.009 & $-0.568 * * *$ & $-2.250 * * *$ & $0.035^{* *}$ & $-1.236^{* * *}$ \\
\hline Non-investment grade & $-0.202^{* * *}$ & $-1.735^{* * *}$ & $-8.868^{* * *}$ & $0.242 * * *$ & -1.566 \\
\hline
\end{tabular}




\section{Table 6}

\section{Loan vs. Bond Choice: Further Controls}

This table re-examines results in Table 3 for different time periods. The specifications are exactly the same as in Table 3, but for compactness of presentation we only report coefficients for the main explanatory variables — tightening in lending standards from Senior Loan Officer Opinion Survey, non-performing loans and loan allowances (both as a fraction of total loans) were compiled from Call Reports, the logarithm of bank stock-index and monetary policy shocks calculated using the federal funds rate deviation from the target level as specified by Taylor-rule. As in Table 3, regressions correspond to the choices of bank loan vs. bond finance. Each observation is a firm-quarter where the firm issued bonds, received a new loan, or both. The dependent variable is a dummy equal to 1 if the firm received a bank loan in that quarter and 0 otherwise. Errors are heteroskedasticity-robust and clustered by quarter. ${ }^{* * *},{ }^{* *}, *$ indicate statistical significance at $1 \%, 5 \%$ and $10 \%$ level, respectively.

\begin{tabular}{|c|c|c|c|c|c|}
\hline \multirow[b]{2}{*}{ Explanatory variable: } & \multicolumn{5}{|c|}{ Dependent variable: Dummy equal 1 if the issue is a loan, 0 if the issue is a bond } \\
\hline & $\begin{array}{c}\text { Tightening in lending } \\
\text { standards }\end{array}$ & Non-performing loans & Loan allowances & Bank stock-index & $\begin{array}{c}\text { Tightening } \\
\text { monetary policy }\end{array}$ \\
\hline Benchmark (Table 3) & $-0.059 * *$ & $-1.030 * * *$ & $-5.122 * * *$ & $0.108 * * *$ & $-1.617 * * *$ \\
\hline \multicolumn{6}{|l|}{ Further controls: } \\
\hline Financing amount (log, real) & $-0.057 * *$ & $-1.113^{* * *}$ & $-5.550 * * *$ & $0.111^{* * *}$ & $-1.601^{* * *}$ \\
\hline Time to maturity & $-0.067 * *$ & $-1.043 * * *$ & $-5.728 * * *$ & $0.117 * * *$ & $-1.209 * * *$ \\
\hline Yield, amount, maturity & $-0.114^{* * *}$ & $-1.501 * * *$ & $-8.323 * * *$ & $0.140 * * *$ & -0.843 \\
\hline \multicolumn{6}{|l|}{ Prior issuance filter: } \\
\hline Bond issues in last 2 years & $-0.069 * * *$ & $-0.783 * * *$ & $-3.767 * * *$ & $0.069 * * *$ & $-1.226 * * *$ \\
\hline No filter & -0.017 & $-1.283^{* * *}$ & $-5.892 * * *$ & $0.112 * * *$ & $-1.866 * * *$ \\
\hline Excluding crisis (2007-2009) & $-0.047^{*}$ & $-0.045^{*}$ & $-3.570^{* * *}$ & $0.089 * * *$ & $-1.738 * * *$ \\
\hline \multicolumn{6}{|c|}{ Fixed effects (Firm*Time window): } \\
\hline 10 years & $-0.098 * * *$ & $-1.165^{* * *}$ & $-7.085 * * *$ & $0.083^{* * *}$ & -0.843 \\
\hline 5 yeas & $-0.105^{* * *}$ & $-1.187 * * *$ & $-6.708 * * *$ & $0.134 * * *$ & $-1.347^{*}$ \\
\hline 4 years & $-0.067 * *$ & $-0.936 * * *$ & $-5.897 * * *$ & $0.083^{* *}$ & -0.756 \\
\hline
\end{tabular}




\section{Table 7}

\section{Including Short Term Financing: Commercial Paper and Revolving Credit Lines}

In this table we relax our definition of bank credit and bond debt to include revolving credit and commercial paper issues. In each row, the regression only includes observations for firms which have accessed the market in the last five years (i.e. twenty quarters). This access refers to bonds in the first row, commercial paper in the second, and either type of security in the third. In each regression, firm-quarters where both types of financing occur are excluded. *** , ** , * indicate statistical significance at $1 \%, 5 \%$ and $10 \%$ level, respectively.

Dependent variable: Dummy equal 1 if the issue is a loan, 0 if the issue is a bond

\begin{tabular}{|c|c|c|c|c|c|c|c|}
\hline \multirow[b]{2}{*}{ Explanatory variable: } & \multirow[b]{2}{*}{ Mean } & \multirow[b]{2}{*}{ Obs. } & \\
\hline & & & $\begin{array}{c}\text { Tightening in } \\
\text { lending standards }\end{array}$ & $\begin{array}{l}\text { Non-performing } \\
\text { loans }\end{array}$ & Loan allowances & $\begin{array}{l}\text { Bank stock- } \\
\text { index } \\
\end{array}$ & $\begin{array}{c}\text { Tightening } \\
\text { monetary policy }\end{array}$ \\
\hline Term loans vs. bonds (Table 3) & 0.135 & 9,670 & $-0.059 * *$ & $-1.030 * * *$ & $-5.122 * * *$ & $0.108 * * *$ & $-1.617^{* * *}$ \\
\hline Revolvers vs. commercial paper & 0.676 & 2,165 & $-0.158 * * *$ & -0.216 & -1.888 & $0.284 * * *$ & $-2.298 * *$ \\
\hline $\begin{array}{l}\text { Term loans and revolvers vs. } \\
\text { bonds and commercial paper }\end{array}$ & 0.402 & 13,080 & $-0.222 * * *$ & $-1.854 * * *$ & $-8.446 * * *$ & $0.298 * * *$ & $-2.772 * * *$ \\
\hline
\end{tabular}




\section{Table 8}

\section{Out-of-sample Prediction Effect of the Loan-Bond Substitution Measure}

This table uses sample of firms not used in the analysis in Table 3. Each observation in the sample corresponds to a firm-quarter. The dependent variable is a dummy equal to 1 if the firm received a bank loan in that quarter and 0 otherwise. Firms are included this sample as long as they have not issued bonds. The table reports results of the linear regressions for the period 1990:Q2 to 2010:Q4. The focus is on Loan-to-bond substitution defined as the fraction of firms which used bank credit among those firms that receive only one type of financing in a given quarter. As before, data on tightening in lending standards comes from Federal Reserve Senior Loan Officer Opinion Survey on Bank Lending Practices. The series corresponds to the net percentage of domestic respondents tightening standard for commercial and industrial (C\&I) loans to large and medium-sized firms. Non-performing loans to equity ratio was compiled from Call Reports and correspond to market capitalization value-weighted averages for large banks with available information. Bank stock-index is the logarithm of the level of the market-adjusted price for banks (industry \#11) available from Kenneth French's data library. Monetary policy is based on the federal funds rate deviation from the target level as specified by Taylor-rule. Firm controls are the log of assets (lagged), the log of property, plant and equipment (lagged), the return on assets (operating income before depreciation divided by previous quarter's assets), one year lagged return to the end of the previous quarter, leverage (long term debt over assets) and two dummies indicating whether a firm pays a dividend and repurchased shares (according to cash flow statement) in the current quarter, respectively. Standard errors are heteroskedasticity-robust and clustered by quarter. ***, **, * indicate statistical significance at $1 \%$, 5\% and $10 \%$ level, respectively.

\begin{tabular}{|c|c|c|c|c|c|c|c|}
\hline \multicolumn{8}{|c|}{ Dependent variable: Dummy equal 1 if the firm receives a new loan in the quarter, 0 otherwise } \\
\hline Dependent variable mean: & $\begin{array}{c}0.012 \\
(1)\end{array}$ & $\begin{array}{c}0.012 \\
(2)\end{array}$ & $\begin{array}{c}0.012 \\
(3)\end{array}$ & $\begin{array}{c}0.012 \\
(4)\end{array}$ & $\begin{array}{c}0.012 \\
(5)\end{array}$ & $\begin{array}{c}0.012 \\
(6)\end{array}$ & $\begin{array}{c}0.012 \\
(7)\end{array}$ \\
\hline Tightening in lending standards & $\begin{array}{c}-0.021 \\
(0.019)\end{array}$ & & & & & & $\begin{array}{c}0.002 \\
(0.003)\end{array}$ \\
\hline Non-performing loans /Equity & & $\begin{array}{c}-0.053^{* * *} \\
(0.012)\end{array}$ & & & & & $\begin{array}{c}0.014 * * \\
(0.056)\end{array}$ \\
\hline Loan allowances & & & $\begin{array}{c}-0.262 * * * \\
(0.060)\end{array}$ & & & & $\begin{array}{c}-0.694^{* *} \\
(0.307)\end{array}$ \\
\hline Bank stock-index & & & & $\begin{array}{c}0.067 * * * \\
(0.018)\end{array}$ & & & $\begin{array}{c}0.002 \\
(0.003)\end{array}$ \\
\hline Tightening monetary policy & & & & & $\begin{array}{c}-0.013 \\
(0.024)\end{array}$ & & $\begin{array}{c}0.000 \\
(0.024)\end{array}$ \\
\hline Loan-to-bond substitution & & & & & & $\begin{array}{c}\mathbf{0 . 0 2 2} * * * \\
(0.004)\end{array}$ & $\begin{array}{c}\mathbf{0 . 0 2 7} * * * \\
(0.008)\end{array}$ \\
\hline Firm controls & Yes & Yes & Yes & Yes & Yes & Yes & Yes \\
\hline Firm fixed effects (Obs.) & Yes $(3,896)$ & Yes $(3,870)$ & Yes $(3,870)$ & Yes $(3,896)$ & Yes $(3,896)$ & Yes $(3,896)$ & Yes $(3,178)$ \\
\hline Clusters & 78 & 68 & 68 & 78 & 78 & 78 & 68 \\
\hline$R$-squared & 0.09 & 0.09 & 0.09 & 0.09 & 0.09 & 0.09 & 0.10 \\
\hline Observations & 73,581 & 72,441 & 72,441 & 73,581 & 73,581 & 73,581 & 51,414 \\
\hline
\end{tabular}




\section{Table 9}

\section{Real Effects of Loan Supply}

Each observation in the sample corresponds to a firm in a given quarter. The dependent variable is investment in property, plant and equipment over lagged assets. The table reports results of the linear regressions for the period 1990:Q2 to 2010:Q4. The focus is on Loan-to-bond substitution defined as the fraction of firms which used bank credit among those firms that receive only one type of financing in a given quarter (conditional on the set of firms with access to bond markets). High leverage is a dummy variable equal to 1 for firms with leverage above the industry median and 0 otherwise. Low $Q$ is a dummy variable equal to 1 for firms with market-to-book valuation below the industry median and 0 otherwise. Firm controls are the log of assets (lagged), the log of property, plant and equipment (lagged), the return on assets (operating income before depreciation divided by previous quarter's assets), one year lagged stock return to the end of the previous quarter, leverage (long term debt over assets) and two dummies indicating whether a firm pays a dividend and repurchased shares (according to cash flow statement) in the current quarter, respectively. Errors are heteroskedasticity-robust and clustered by quarter. ***, **, * indicate statistical significance at $1 \%, 5 \%$ and $10 \%$ level, respectively.

\begin{tabular}{|c|c|c|c|c|}
\hline \multicolumn{5}{|c|}{ Dependent variable: Quarterly change in Property Plant and Equipment as a \% of lagged assets } \\
\hline \multirow[t]{2}{*}{ Dependent variable mean: } & 0.016 & 0.019 & 0.019 & 0.019 \\
\hline & Bond access & \multicolumn{3}{|c|}{ No bond access } \\
\hline Firm sample: & $\begin{array}{l}\text { All } \\
(1)\end{array}$ & $\begin{array}{l}\text { All } \\
(2)\end{array}$ & $\begin{array}{c}\text { High leverage/ } \\
\text { Low Q } \\
(3)\end{array}$ & $\begin{array}{l}\text { All } \\
(4) \\
\end{array}$ \\
\hline Loan-to-bond substitution & $\begin{array}{l}0.009 * * \\
(0.004)\end{array}$ & $\begin{array}{l}0.013 * * \\
(0.006)\end{array}$ & $\begin{array}{l}0.014 * * \\
(0.006)\end{array}$ & $\begin{array}{l}0.001 \\
(0.007)\end{array}$ \\
\hline Loan-to-bond substitution x Leverage & -- & -- & -- & $\begin{array}{l}0.124^{* * *} \\
(0.014)\end{array}$ \\
\hline Loan-to-bond substitution x Low Q & -- & -- & -- & $\begin{array}{l}-0.005^{*} \\
(0.003)\end{array}$ \\
\hline Log (Assets) & $\begin{array}{l}-0.005^{* * *} \\
(0.001)\end{array}$ & $\begin{array}{l}-0.004^{* * *} \\
(0.001)\end{array}$ & $\begin{array}{l}0.001 \\
(0.003)\end{array}$ & $\begin{array}{l}-0.004^{* * *} \\
(0.001)\end{array}$ \\
\hline $\log (\mathrm{PP} \& \mathrm{E})$ & $\begin{array}{l}-0.001 * * * \\
(0.000)\end{array}$ & $\begin{array}{l}0.002 \\
(0.002)\end{array}$ & $\begin{array}{l}-0.008^{* * *} \\
(0.003)\end{array}$ & $\begin{array}{l}-0.002 \\
(0.004)\end{array}$ \\
\hline ROA & $\begin{array}{l}0.087^{* * * *} \\
(0.001)\end{array}$ & $\begin{array}{l}0.038^{* * * *} \\
(0.006)\end{array}$ & $\begin{array}{l}0.096 * * * \\
(0.024)\end{array}$ & $\begin{array}{l}0.040 * * * \\
(0.006)\end{array}$ \\
\hline Market-to-book & $\begin{array}{l}0.0042^{* * *} \\
(0.006)\end{array}$ & $\begin{array}{l}0.003^{* * *} \\
(0.001)\end{array}$ & $\begin{array}{l}0.003^{* * *} \\
(0.004)\end{array}$ & $\begin{array}{l}0.006^{* * *} \\
(0.001)\end{array}$ \\
\hline Lagged return & $\begin{array}{l}0.002 * * * \\
(0.001)\end{array}$ & $\begin{array}{l}0.002^{* * *} \\
(0.000)\end{array}$ & $\begin{array}{l}0.001 \\
(0.001)\end{array}$ & $\begin{array}{l}0.002^{* * *} \\
(0.001)\end{array}$ \\
\hline Leverage & $\begin{array}{l}-0.030 * * \\
(0.002)\end{array}$ & $\begin{array}{l}-0.021^{* * *} \\
(0.002)\end{array}$ & $\begin{array}{l}-0.053^{* *} \\
(0.008)\end{array}$ & $\begin{array}{l}-0.057^{* * *} \\
(0.006)\end{array}$ \\
\hline Dividend payer & $\begin{array}{l}0.001 \\
(0.001)\end{array}$ & $\begin{array}{l}0.002^{*} \\
(0.001)\end{array}$ & $\begin{array}{l}0.000 \\
(0.000)\end{array}$ & $\begin{array}{l}-0.003^{* *} \\
(0.001)\end{array}$ \\
\hline Firm fixed effects (Obs.) & Yes $(2,046)$ & Yes $(2,746)$ & Yes $(1,031)$ & Yes $(2,715)$ \\
\hline Clusters (quarter) & 84 & 84 & 77 & 84 \\
\hline$R$-squared & 0.28 & 0.31 & 0.20 & 0.28 \\
\hline Observations & 46,670 & 35,097 & 7,393 & 34,848 \\
\hline
\end{tabular}




\section{Appendix}

In this appendix we present a simple model of the choice between bank loans and bonds. This setting looks at a static choice between two perfectly substitutable sources of funding, subject only to a limit in the availability of the cheaper source.

The firm output function is $f(K)$, with $f^{\prime}>0$ and $f^{\prime \prime}>0$. The firm has no internal funding and has to raise $K$ externally. A firm is borrowing $L$ from a bank and $B$ from the bond market:

$$
K \leq L+B
$$

The bank has an upper limit $D$ on the loan it may extend. This is a fixed amount of financing the bank has, one can think of it as a deposit base which cannot be easily increased:

$$
L \leq D
$$

The cost of deposits for the bank is $R$, and loans are competitively priced so that the bank charges $R$ to the borrower. The bond market supplies bonds in the amount $B$ at cost $y(B)$ with $y^{\prime}>0$ and $y^{\prime \prime}>0$.

The firm's problem is

$$
\max f(K)-y(B)-L R
$$

The first order condition with respect to borrowing is:

$$
f_{K}(L+B)=R
$$

To ensure that the firm utilizes both forms of funding in its optimum, we simply assume that

$$
f_{K}>R, \quad \forall K
$$

Under assumption (4), constraint (2) is binding, and the firm maximizes the loan it gets, so that $L=D$. The first order condition with respect to $B$ is:

$$
f^{\prime}(L+B)-y^{\prime}(B)=0
$$

Using $L=D$ this becomes

$$
f^{\prime}(D+B)=y^{\prime}(B)
$$

We can differentiate (5) with respect to bank-loan supply $D$, allowing $B$ to vary with $D$ :

$$
f^{\prime \prime}(D+B)\left[1+B_{D}\right]=y^{\prime \prime}(B) B_{D}
$$

Finally, we can solve for $B_{D}$ : 


$$
B_{D}=\frac{f^{\prime \prime}}{y^{\prime \prime}-f^{\prime \prime}}<0
$$

The sign follows from the assumptions made about the functions $f$ and $y$. Equation (7) shows that the quantity of bonds issued goes down when loan supply $D$ increases, and up when $D$ decreases. In other words, firms substitute between bonds and loans. When banks lend less, bond issuance goes up in response.

What about price of bonds? We take the total derivative of $y(B)$ with respect to $D$ :

$$
\frac{\partial y}{\partial D}=y^{\prime}(B) B_{D}<0
$$

Bond yields go up when the loan supply falls; as firms are getting more funding out of the bond market, the price of bond funding is pushed up.

The predictions of the model, as derived in equations (7) and (8), are consistent with the empirical findings in our paper. They key assumption is that the bank lending market is not clearing through price. This may reflect various frictions, including rationing as in Stiglitz and Weiss (1981). However, this is a particularly simple setting and it is reasonable to ask if these predictions are specific to our simple set-up. In fact, they are not. Holmström and Tirole (1997) derive an equilibrium with some similar properties, as can be seen from their equation (9):

$$
\int_{A(\gamma, \beta)}^{\infty}(I-A) d G(A)=S(\gamma)+K_{m}
$$

Here, the integral on the left side characterizes the economy's output. Bank lending $K_{m}$ is fixed and the bond price $\gamma$ will move to equate capital demand and supply through the variable quantity $S$ of bonds outstanding. There are two important differences. First, in Holmström and Tirole (1997) each firm has one kind of debt only, and the equation characterizes capital market equilibrium for the aggregate market. Second, in the Holmström and Tirole model, the two forms of funding are not perfect substitutes. Individual firms use one form of financing or the other. In particular, bank loans are expensive, but monitoring makes them available to firms with no bond market access. This illustrates that the simplifying assumptions of our model generate predictions that are more general. In the Holmström and Tirole model, a different set of frictions in a more complex model results in similar equilibrium properties. 